\title{
A INTEGRALIDADE \\ NUMA REDE DE PROTEÇÃO SOCIAL AO ADOLESCENTE \\ UM OLHAR FENOMENOLÓGICO
}

SANDRO DA ROCHA VIEIRA

\author{
Dissertação de mestrado apresentada \\ à da Faculdade de Saúde Pública \\ da Universidade de São Paulo \\ Área de concentração: \\ Saúde Materno-Infantil
}

ORIENTADOR: PROF. DR. CORNÉLIO PEDROSO ROSENBURG

SÃO PAULO

JAN/2008 


\section{DEDICATÓRIA}

"Para ser grande sê inteiro. Põe quanto és no mínimo que fazes."

Alberto Reis

Dedico esta dissertação a todas crianças e adolescentes do Município de Suzano e ao meu grande amigo Valdemir Bevilacqua que, pacientemente, muito me apoiou e incentivou nessa jornada. 


\section{AGRADECIMENTOS}

Ao Professor Doutor Cornélio P. Rosenburg - meu orientador -, que nas inúmeras tardes de quarta-feira, embalados ao perfume de tabaco e degustação de um bom café mergulhávamos em sua sabedoria filosófica produzindo um conhecimento de qualidade e transdisciplinar.

Ao Lasamec - Laboratório de Saúde Mental Coletiva, na pessoa do Professor Doutor Alberto Olavo A. Reis que, agregando uma equipe interdisciplinar, em suas pontuais contribuições muito me inspirou no saber em saúde coletiva.

Às Professoras Doutoras Augusta T. de Alvarenga, Néia Schor e Fumika Peres pelo empenho em garantir a qualidade metodológica da produção científica na pesquisa qualitativa no campo da Saúde Pública.

À Secretaria do Departamento de Saúde Materno Infantil/FSP, na pessoa do Sr. Leandro Cleto sempre disponível e empenhado em informar e apoiar nos momentos de maiores apuros. 


\section{APRESENTAÇÃO}

A proposta desta investigação emerge das vivências que foram se configurando em questionamento a partir da experiência como agente social numa intersecção entre os campos da saúde e da promoção social.

Essas vivências foram se delineando desde a vida pessoal e familiar às experiências profissionais na condição de professor de filosofia no Ensino Médio, da Rede Pública Estadual. E, como Psicólogo Clínico, na atuação junto a entidades sociais de atenção ao adolescente. Preocupações quanto à concepção de integralidade na atenção psicossocial destinada ao adolescente me desafiaram e incitaram-me a melhor compreendê-la.

Minha aproximação aconteceu ao observar o empenho de muitos trabalhadores e instituições em fortalecer propostas inovadoras de intervenção junto ao adolescente. No compromisso seja da saúde, da assistência social ou educação, em compreender o fenômeno da integralidade na atenção ao adolescente.

O foco de nosso estudo tem como preocupação a concepção de integralidade protagonizado por agentes sociais numa rede de atenção psicossocial ao adolescente no município de Suzano, em São Paulo. 


\begin{abstract}
The investigation has tried to comprehend the integrality notion of the Adolescent and Child Social Protection, in the city of Suzano, wich an important part of social and health agent's practice forms from. For that, an empiric exploration of those actors' discursive elements was conducted. The experiences collected in the field have allowed the understanding and reflexion of the notion of integrality in the Public Health Insurance knowledge. The research objectives were, as a priority, to characterize and put the integrality place inside that protection net in doubt; describing the experiences and reflecting over the integral attention at the action articulation inside the service net. The phenomenology was chosen as a methodological reference, setting itself up as two moments articulated between themselves: participant observation and semi-structured interviews. The subjects of the research were the Conselho Municipal de Defesa dos Direitos da Criança e Adolescente members, as articulators of the adolescent and child care city policy. The research was able to comprehend the integrality notion as idea/reference, concept which has emerged from the social agent searched and from which derives its actions in the adolescent health field, mainly on what concerns a psychosocial care.
\end{abstract} Key words: integrality, adolescent health and psychosocial care. 


\section{RESUMO}

A investigação procurou compreender a noção de integralidade na Rede de Proteção Social à Criança e ao Adolescente, na Cidade de Suzano/SP, acerca da qual deriva parte importante da prática de agentes sociais e de saúde. Para tanto procedeu-se a uma exploração empírica dos elementos discursivos desses atores. As experiências colhidas em campo permitiram a compreensão e reflexão da noção de integralidade no campo de conhecimento da Saúde Pública. Os objetivos da pesquisa tiveram por prioridade: caracterizar e problematizar o lugar da integralidade no interior dessa rede de proteção; descrevendo as experiências e refletindo sobre a atenção integral na articulação de ações no interior da rede de serviços. A fenomenologia foi escolhida como referencial metodológico compondo-se por dois momentos articulados entre si: observação participante e entrevistas semi-estruturadas. Os sujeitos de pesquisa foram os membros do Conselho Municipal de Defesa dos Direitos da Criança e do Adolescente na qualidade de articuladores da política municipal de atenção ao adolescente. A pesquisa foi capaz de compreender a noção de integralidade como idéia/referência, conceito que emergiu no discurso dos agentes sociais pesquisados, e da qual derivam suas ações no campo da saúde do adolescente, sobretudo no que tange a uma atenção psicossocial.

Descritores: integralidade, saúde do adolescente e atenção psicossocial 


\section{ÍNDICE}

\section{Agradecimentos}

\section{Apresentação}

\section{Resumo}

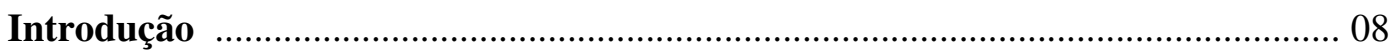

1. As diversas concepções de integralidade .................................................... 10

1.2. A integralidade na atenção psicossocial ao adolescente ............................... 13

\section{Método}

1. Uma aproximação à fenomenologia no contexto deste estudo ............................. 22

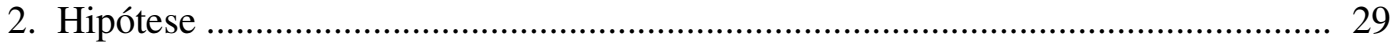

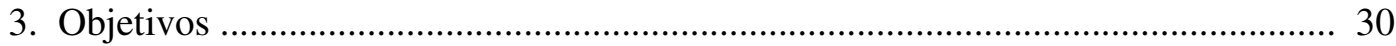

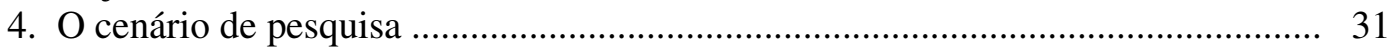

5. Seleção dos sujeitos de pesquisa ........................................................................ 35

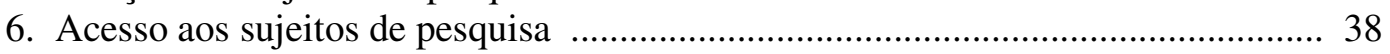

7. Coleta dos dados: observação participante e entrevista semi estruturada ............... 41

8. Sistematização dos dados coletados ................................................................ 48

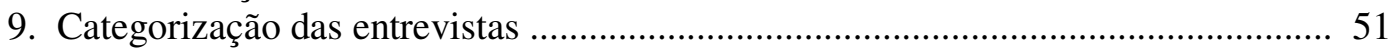

\section{Resultados e discussão}

1. A compreensão de integralidade como um paradigma - idéia referência ............. 67

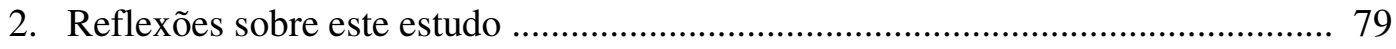

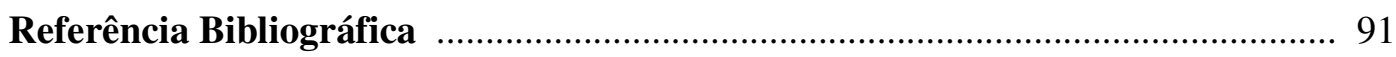

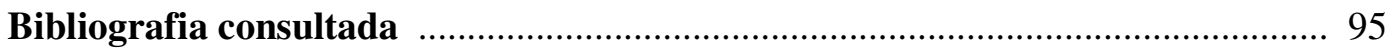

\section{Anexo}

1. Termo de consentimento esclarecido 


\section{INTRODUÇÃO}

"Quando de manhã cedo um físico sai de casa para ir pesquisar no laboratório o efeito de Compton e sente brilhar nos olhos o raios de sol, a luz não lhe fala em primeiro lugar, como fenômeno, de uma mecânica quântica ondulatória... A luz fala, sobretudo, de um mundo em que ele nasce e cresce, ama e odeia, vive e morre, a todo instante. Sem esse mundo originário, o físico não poderia empreender suas pesquisas, pois não lhe seria possível nem mesmo existir... Nem o Sol está somente fora de nós, nem a luz está exclusivamente dentro de nós, porque sempre e necessariamente realizamos nossa existência na estrutura ser-no-mundo"

(Leão, em Heidegger, 1988: 19)

É nos cenários do contemporâneo que queremos inserir a discussão sobre integralidade. Apreender esse tema no âmbito de uma rede de proteção social ao adolescente se tornou imprescindível por possibilitar a compreensão dos desafios que a fragmentação e o reducionismo impõem aos atores sociais no cotidiano de suas ações.

O cotidiano se apresentou como lugar privilegiado no qual interagem os atores sociais que contribuíram na compreensão do fenômeno ao qual nos propomos pesquisar.

A cotidianidade, como modo comum do mundo, é o lugar onde se adensa a realização da existência humana. Aquela mostra que esta se perfaz numa série de afazeres que nos recriam a cada dia, nos identificam e nos fazem existir. Nos afazeres do cotidiano vamos à compreensão de nós mesmos e dos entes do mundo que não somos nós. A primeira compreensão é existencial, a segunda é categorial.

A compreensão existencial se refere diretamente ao nosso ser e se forma lentamente, trabalhando em nós mesmos, transformando-nos. Os conceitos existenciais que vamos formulando ao longo da vida nos concedem determinada cosmovisão. E é deste lugar, envolvidos na nossa existencialidade, que olhamos para o mundo e o 
transformamos em categorias - conjuntos de significados que classificam a realidade segundo determinado interesse.

No cotidiano do universo contemporâneo é comum as pessoas perderem a noção do limite entre suas existências e suas categorias. Viverem massificadas entregues ao espetaculoso 'show da vida', a realizações de imagens filtradas pela publicidade de consumo. Como nos ensinou Heidegger que a massificação não diz ser menos nem um grau inferior de ser. Ao contrário, a massificação pode determinar uma existência humana mais cheia em seus ofícios, estímulos, interesses e prazeres.

Devido a esta situação, ao lançarmos o olhar para o campo da saúde, veremos que proliferam movimentos de cura sedimentados em modelos pseudopsicoterapêuticos, em modelos "ecológicos" de retorno ao primordial, à inocência da natureza ou em modelos sócio-políticos que prometem a sonhada reforma econômicosocial. Tais movimentos não eliminam o desconforto social e o que se sente é a vazia loquacidade, a pseudocomunicação.

Por certo, a existência-humana-no-mundo se expressa no discurso do dia-a-dia. Tornamos a realidade vivida em palavras. No cotidiano corremos o risco da conversa "fiada" e dos jargões. As coisas são faladas de modo flutuante, sem bases sólidas. As descobertas da ciência se tornam jargões da curiosidade espetaculosa dos meios de comunicação, substituindo a seriedade da pesquisa, obscurecem e freiam a investigação crítica. 
Vivemos numa época de perda do sentido das palavras que enunciam determinados princípios. Nessa situação princípios, como a integralidade, correm terríveis ameaças. Apesar desse contexto, por toda parte, a ciência incrementa o exercício da pesquisa e construção de palavras autênticas que revelem, que construam realidades mais saudáveis.

Assim, consideramos que a integralidade seja um princípio que devamos considerar de forma expressiva no cotidiano das práticas em saúde pública, principalmente na atenção ao adolescente.

\section{As diversas concepções de integralidade}

Ao tomarmos a palavra integralidade, num contexto de pesquisa no campo da saúde pública, somos remetidos a uma aproximação com o Sistema Único de Saúde, o SUS. Desde os anos oitenta a integralidade foi se revelando como um paradigma nas políticas governamentais, em programas de intervenção e em todo o discurso do movimento sanitário brasileiro. Na Constituinte de 1988, em que se estabeleceu o SUS, a integralidade foi definida como uma de suas diretrizes básicas. Desde então, surgiu uma polissemia sobre esse termo - que de forma alguma é unívoco. Mais do que isso, se tornou o diferencial brasileiro de toda a tendência mundial na área da saúde desde a época de sua implantação. Entender essa noção polissêmica significa, então, compreender a especificidade do SUS em nosso país em seu projeto de atuação.

No âmbito do SUS a integralidade foi pensada, primeiro, em termos de uma articulação entre aparatos institucionais prestadores de serviços, como a integração entre 
os setores público e privado na produção dos cuidados de assistência médica, ou entre os sub-setores de saúde pública e de medicina previdenciária, no interior do próprio setor público de serviços; depois, foi pensada como um problema de gerência dos serviços. De qualquer modo, a integralidade em saúde esteve sempre explicitada como intenção e necessidade da ação pública, isto é, as intervenções que consolidariam, enfim, o SUS. E, neste plano, a ação pode ser pensada em duas esferas; a ação norteadora de projetos técnico-sociais; e, a ação que os realiza em serviços, produzindo diretamente cuidados, desenhando as organizações compatíveis com o modelo assistencial de saúde antevisto como projeto técnico e, ao mesmo tempo, social ( Ferla e col., 2003).

A integralidade apresenta-se como o maior desafio nas práticas em saúde. Não como questão apenas institucional ou política. Pois, integrar na esfera que contém a política e ação públicas (em que ocorre a prestação dos serviços), considerando o público como um setor de produção social, não é exatamente algo novo. Mas, como desafio cultural, para romper com formas cristalizadas de se entender e realizar ações técnicas e que conformam padrões de intervenção médica ou em saúde tornados tradição. Por exemplo, pertencem ao agir tradicional as ações especializadas, as ações do conhecimento científico progressivamente cristalizado (formas especializadas de desempenho técnico e profissional), pois são elas que identificamos com o melhor da ciência - traduzem o isolamento do trabalho especializado. É desse isolamento que se alimenta sua característica positiva. Isto é, a ação especializada deriva de conhecimento de campo restrito, mas muito aprofundado, e, em seu campo de ação, com progressivo poder de cura. Prescindimos de lembrar as várias conquistas que fizeram a ciência e as tecnologias médicas. Paradoxalmente, é também desse isolamento que derivam os 
impactos negativos da ação especializada, apresentando riscos para a saúde do indivíduo e, da coletividade (Mattos, 2001:39-63).

Nessa perspectiva encontramos na integralidade, "uma imagem objetivo, uma noção amálgama, com vários sentidos" (Costa, 2004). Que foi forjada a partir de um lugar de oposição, de crítica radical às práticas, instituições e organização do sistema de saúde anterior ao SUS.

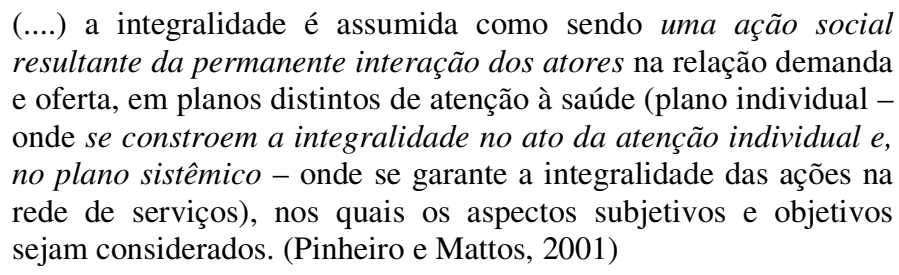

Segundo Pinheiro e colaboradores $(2001,2003)$ um primeiro conjunto de sentidos da integralidade remete à medicina integral, que criticava a atitude cada vez mais fragmentária dos médicos diante dos pacientes, responsabilizando por isso as escolas médicas. Para esse grupo, então, a integralidade estava associada à atitude e, portanto, à boa prática médica.

Com o nascimento da Saúde Coletiva no Brasil, nos anos setenta, influenciada pela medicina preventiva e pela medicina integral a fragmentação da medicina passou a ser atribuída à racionalidade médica e não mais ao comportamento. Com o tempo, a saúde coletiva se afastou das questões relativas à prática médica propriamente dita e, conseqüentemente, diminuiu a importância da noção de integralidade como uma atitude médica desejável. Mas as influências deixadas pela medicina integral podem ser encontradas em alguns aspectos: 
- Integralidade a partir do referencial da Medicina Integral. Como crítica a atitude médica fragmentária, a um sistema que privilegia a especialização e segmentação, recusa a atitude médica reducionista, a formação médica de base flexneriana que reduz o paciente ao aparelho ou sistema biológico que supostamente produz o sofrimento e, portanto, à queixa do paciente.

- Integralidade a partir do referencial da Medicina Preventiva. Como crítica aos profissionais de saúde, numa dimensão das práticas, buscar compreender o conjunto das necessidades de ações e serviços de saúde que um paciente apresenta para além da atenção individual curativa, incorporando ações de promoção e prevenção na atenção à saúde e articulação com ações curativas e reabilitadoras.

Ainda, segundo Pinheiro e colaboradores (2001, 2003), um segundo conjunto de sentidos da integralidade refere-se à organização dos serviços e práticas de saúde. Aqui, esse princípio representa uma crítica à dissociação entre as práticas de saúde pública e as assistenciais, marca do antigo Sistema Nacional de Saúde. É inadmissível, por exemplo, que um diabético, com tuberculose e hérnia inguinal tenha que dar entrada em três pontos distintos do sistema de saúde para encaminhar a solução de seus problemas. Para dar conta disso, a integralidade exige certa horizontalização de modelos que eram, até então, verticais. Nesse caso, a integralidade não é mais uma atitude, mas uma marca no modo de organização do processo de trabalho:

- Integralidade como horizontalização dos programas. Como modo de organizar as práticas relaciona-se à organização dos serviços e das práticas de saúde, 
crítica à separação entre práticas de saúde pública e práticas assistenciais, entre ações de saúde coletiva e atenção individual, crítica aos programas verticais.

- Integralidade como oferta de programas de atenção à saúde. Inova o modo de organizar o processo de trabalho em saúde, aperfeiçoa o seu impacto epidemiológico - articulando atenção e demanda espontânea -, com a oferta programada de atenção à saúde, na busca contínua de ampliar as possibilidades de apreensão e satisfação das necessidades de um grupo populacional, ampliando a eficiência.

- Integralidade como acesso a diversos níveis de atenção. Articulação a partir da atenção básica aos meios de diagnóstico e atenção especializada quando necessária ampliação de acesso ao sistema de saúde e resolutividade da atenção.

- Integralidade como ampliação do horizonte de intervenção sobre problemas. Construção de políticas especificamente desenhadas para dar respostas a um determinado problema de saúde ou aos problemas de saúde que afligem um determinado grupo populacional, articulação intra e intersetorial, ampliando os âmbitos e articulação de diversos espaços para a busca de soluções à qualidade de vida.

As ações de saúde devem, portanto, ser combinadas e voltadas ao mesmo tempo para prevenção e a cura. Os serviços de saúde devem funcionar atendendo o indivíduo como um ser humano integral submetido às mais diversas situações de vida e trabalho, que o levam ao adoecer e ao morrer. Compreendido como ser humano numa perspectiva sócio-política, é o cidadão que biológica, psicológica e culturalmente está sujeito a riscos. Desta forma o atendimento deve ser feito para a sua saúde e não somente para a 
sua doença. Isto exige que o atendimento seja feito também para erradicar as causas e diminuir os riscos, além de tratar os danos.

É o que rege o texto constitucional quando assevera caber ao Estado a tarefa de garantir a saúde para todos, através de políticas sociais e econômicas voltadas tanto para a "redução do risco de doença e de outros agravos", quanto "ao acesso universal e igualitário a ações de serviços para sua promoção, proteção e recuperação" (Constituição do Brasil, 1988).

Pinheiro e Mattos $(2001,2003)$ apresentam, ainda, um terceiro conjunto de sentidos da integralidade que está relacionado às políticas chamadas especiais, voltadas para grupos específicos. Um exemplo é o Programa de Assistência Integral à Saúde da Mulher, do Adolescente, entre outros, cujo argumento é a necessidade de os problemas de saúde serem contextualizados. Essa noção de integralidade associada às políticas mostra também que cabe ao governo responder aos problemas de saúde pública, em relação tanto à prevenção quanto à assistência. Nesse sentido, a resposta do governo brasileiro ao HIV/AIDS talvez seja o que mais se aproxime do princípio da integralidade.

Esses três grandes conjuntos de sentidos de integralidade incidem sobre diferentes pontos: o primeiro conjunto se refere a atributos das práticas dos profissionais de saúde, sendo valores ligados ao que se pode considerar uma boa prática médica, independentemente de ela se dar no âmbito do SUS. O segundo conjunto refere-se a atributos da organização dos serviços; o terceiro aplica-se às respostas 
governamentais aos problemas de saúde. Em qualquer desses significados, e em muitos outros que esse termo possa adquirir, a integralidade representa, acima de tudo, uma proposição ao reducionismo tecnicista na atenção à saúde.

\section{A integralidade numa perspectiva de atenção psicossocial ao adolescente}

Um marco institucional que caracteriza um novo olhar sobre o adolescente no Brasil foi a promulgação da lei 8069/90, que criou o Estatuto da Criança e do Adolescente - ECA. Sabemos que essa lei foi o resultado de uma intensa movimentação dos setores sociais organizados que buscaram criar um novo espaço político e jurídico para a criança e o adolescente brasileiros. O ECA substituiu o Código de Menores, sinalizando para uma legislação que garantisse, pelo Estado, o desenvolvimento integral das crianças e dos adolescentes.

O Estatuto da Criança e do Adolescente para alcançar o objetivo da "proteção integral" instituiu uma ação conjunta entre governo e sociedade, implementada na criação de Conselhos dos Direitos da Criança e do Adolescente nos âmbitos dos governos federal, estadual e municipal. Articulando um projeto político de proteção e promoção à criança e ao adolescente em que governo e sociedade civil se comprometam com essa política de forma efetiva, como um todo.

A criação do Estatuto da Criança e do Adolescente situa-se no contexto da então recente promulgação da Constituição do Brasil, em 1988, em que foi instituída uma nova dimensão à sociedade brasileira garantindo-lhe os diretos democráticos de 
participação cidadã e a consolidação do Estado de Direito. O país vivia numa ambiência de redemocratização das instituições políticas e sociais. Uma das instituições sociais que conseguiu propor e implantar novos paradigmas epistemológicos e culturais, enquanto cuidado/promoção do ser humano, como dissemos anteriormente, foi a Saúde com a criação do SUS.

A integralidade como um paradigma no cuidado/promoção do ser humano não se restringe à atenção da saúde como fenômeno biomédico - antônimo de doença -, ou como estrutura burocrática dos serviços de saúde; mas, antes, possibilita uma visão social de saúde, passando a compreender que o homem é, geralmente, mais um produto das suas relações com o seu meio ambiente do que somente com os seus dotes genéticos, ou seja, a saúde de um indivíduo pode ser determinada não só por sua condição biológica, mas pelas circunstâncias existenciais na qual está inserido. Dessa concepção emerge uma conceituação do processo saúde/doença, na qual são levados em consideração os determinantes sociais do adoecimento e os modos de vida apresentando-se como desencadeadores do processo. (Contini e Koller, 2002)

A histórica construção do conceito de saúde é associada às respostas que o homem buscava para o fenômeno da vida e da morte. Como na medicina grega que se desenvolveu através dos filhos de Asclépio, que praticavam a cura baseada no conhecimento empírico. Desses asclepíades laicos surgiu a tradição hipocrática na medicina ocidental, culminando com a produção do Corpus Hippocraticum, volumosos escritos deixados por diferentes corporações asclepsianas, a definição de saúde apontando para a busca de um estado de equilíbrio entre as diferentes influências ambientais, que geram modos de vida e os vários componentes da natureza humana. Em 
outro momento, as descobertas realizadas por Galeano (131-201 d.C.), na dissecação de órgãos, possibilitaram análises comparativas de órgãos bons com os defeituosos. As descobertas fizeram com que fosse predominando o estudo das patologias, em detrimento da investigação sobre a higidez. Dessa forma, o percurso de estruturação da nosologia dos sintomas e natureza das patologias ganhou muitos adeptos, principalmente com os vários estudos realizados na Idade Média. Prevaleceu-se, assim, uma conceituação negativa da saúde, enquanto ausência de doença, visto que a medicina começou a acumular mais conhecimentos sobre doença do que os indicadores e atributos que pudessem definir a sanidade física e mental. (Barros, 2002; Contini e Koller, 2002; Duarte, 2002)

Somente em meados do século vinte começaram a surgir definições de saúde não restritas a aspectos orgânicos, mas procurando abarcar a totalidade do homem envolto no seu meio ambiente, o que parece ser um retorno ao tratado ecológico de Hipócrates. Em 1946, a conceituação de saúde começa oficialmente a mudar: a Organização Mundial da Saúde, na publicação dos seus documentos, expõe no preâmbulo da sua Constituição uma nova definição, reconhecendo que a saúde é um completo estado de bem-estar físico, mental e social, e não apenas distúrbios somáticos. Essa conceituação, apesar do avanço, é ampla e subjetiva. Aparece como algo inatingível, utópico, não levando em consideração as diversas circunstâncias que envolvem o humano.

Parece, então, importante apontar que a relação saúde/homem se dá por meio da instrumentalização do ser humano pela via da informação, que possa potencializar o seu enfrentamento às adversidades da sua vida/existência, ou seja, o seu devir, a sua 
história. Dessa forma, a visão social de saúde, procura compreender o homem em sua integralidade bio-psico-social.

Por outro lado é notória, em nossa atualidade, a emergência de teorias psicológicas de mercado que evidenciam a necessidade de uma saúde integral das crianças e adolescentes centradas no indivíduo. Ao perambular pelas revistarias, livrarias e bancas de jornal nos deparamos com inúmeras publicações na área de autoajuda e desenvolvimento pessoal, que apresentam a busca do sucesso na saúde como uma jornada individual, íntima, em que o sujeito empreende sua viagem solitária em busca da realização pessoal.

Essa cultura, de um psicologismo centrado no indivíduo, fortalece um modelo de saúde que não reconhece valores do processo coletivo. Abre uma imensa lacuna entre os programas de saúde pública e o sujeito de direito. Esconde a responsabilidade social da cultura atual como produtora de mal estar. Esse psicologismo, compreendido como o uso indevido de teorias psicológicas sem considerar a validade e verdade das descobertas da ciência psicológica, impede que se desenvolva a criatividade, o pensar lógico, o senso crítico, a cidadania, entre outras tantas habilidades e competências de cunho comportamental e cognitivo que desenvolvem o valor da saúde como valor social.

O que se pode dizer é que a promoção da saúde, numa perspectiva psicossocial, impõe uma visão sistêmica de saúde, através da compreensão de que fatores relacionados ao modo de vida das pessoas estarão atuando de forma direta nas reais possibilidades de uma vida saudável ou não. Com isso, a concepção de saúde é 
ampliada para além dos limites do indivíduo e da ausência de doença e está ligada a vários aspectos presentes na vida do homem, como moradia, educação, trabalho, etc. Será o equilíbrio desses componentes no cotidiano das pessoas que irá formar o grande mosaico da saúde humana.

O adolescente por sua vez, tem o seu lugar nesse movimento quando em 1989 o Ministério da Saúde apresenta o Programa Nacional de Atenção Integral ao Adolescente, e, em 1993, as Normas de Atenção à Saúde Integral do Adolescente fundamentadas nos princípios que acabamos de elencar.

Para a compreensão integral da saúde do adolescente numa perspectiva psicossocial:

“(....) é fundamental o conhecimento dos aspectos do desenvolvimento normal e patológico, para identificar-se o adolescente de alto risco e partir-se para um trabalho com vistas à promoção da saúde e prevenção de doenças, detecção e tratamento das patologias" (Brasil, 1993(II): 07). "O adolescente deve ser atendido por equipe multiprofissional interessada e capacitada para atendimento integral do indivíduo como um todo biopsicossocial, único e em constante interação com seu meio ambiente" (Brasil, 1993(I): 11).

O adolescente constituído nas e pelas relações sociais e materiais não pode ser compreendido apenas como um sujeito externo à sua dimensão psicológica, nem mesmo, como um fenômeno psicológico que revela aspectos relativos à sua subjetividade; mas como aspectos de um mesmo movimento de construção.

"Entende-se por desenvolvimento psicossocial a capacidade de aquisição progressiva do ser humano de interagir com seu meio ambiente". (idem, p. 37) 
Dessa forma, ao falar em mundo interno da pessoa, é preciso referir-se ao mundo social no qual se constitui. Especificamente, em nossa proposta de estudo, que numa abordagem fenomenológica, se propõe à compreensão do paradigma de integralidade numa perspectiva de atenção psicossocial ao adolescente. Essa abordagem possibilitou-nos determinadas construções teóricas por meio das relações dos agentes sociais em suas interações com a atenção ao adolescente. Enfim, em compreender que o grau de desenvolvimento integral da atenção psicossocial dependerá da estrutura social mais ampla na qual os agentes sociais se encontram inseridos. 


\section{MÉTODO}

A fenomenologia apresenta-se como o caminho metodológico percorrido neste estudo. Caracterizando-se como um modo de construir investigação científica em

ciências sociais, particularmente no campo da saúde pública. É oportuno apontar inicialmente sua escolha fazendo algumas aproximações à sua relevância em relação ao objeto de pesquisa.

Em seguida ao referencial fenomenológico descrevemos o cenário do estudo, qual seja, a Rede de Proteção Social ao Adolescente no Município de Suzano; abordando suas características sócio demográfica, organizacional, a dinâmica de trabalho e a prática dos profissionais envolvidos.

Finalizando apresentamos como ocorreu o acesso aos sujeitos de pesquisa abordando especificidades da pesquisa de campo e alguns delineamentos gerais para a interpretação de entrevistas em fenomenologia.

\section{Uma aproximação à fenomenologia no contexto deste estudo}

Considerando a natureza do objeto de investigação, que enfoca a noção de integralidade no âmbito de uma rede de proteção social ao adolescente, implica considerar que fatores subjetivos e socioculturais, nesta pesquisa, podem ser compreendidos a partir de referenciais fundamentados na fenomenologia.

Objetivamos algumas aproximações a esse referencial, principalmente, voltadas para a compreensão das circunstâncias vividas pelos sujeitos de pesquisa. Fato que 
assevera a necessidade compreender a ótica circunstancial do fato para acessá-lo em sua relação com fenômeno em estudo. Deste modo, vislumbramos a possibilidade da construção de um conhecimento compreensivo sobre o fenômeno da integralidade abarcando sua complexidade. Importante sinalizar que a postura do pesquisador como co-participante no mostrar-se do fenômeno, implicou na sua abertura existencial para a escuta do outro em sua própria experiência de vida.

Um ponto inicial a ser considerado é que, na pesquisa fenomenológica, o pesquisador não terá um problema, mas uma interrogação. Quando o pesquisador interroga, ele está focalizando o fenômeno e não o fato. As idéias de fato têm seus fundamentos na lógica e no positivismo clássico, sendo concebidas como tudo aquilo que pode tornar-se mensurável e objetivo como objeto de ciência (Boemer, 1994). O pesquisador, na perspectiva da fenomenologia, parte da interrogação sobre o fenômeno, cuidando para que teorias e princípios estabelecidos sobre o tema não determinem sua trajetória. A inquietação de algo que está oculto e precisa ser desvelado é a gênese de uma interrogação que dirige a busca da compreensão fenomenológica.

Compreendemos que um fato implica considerar aspectos objetivos da realidade expressos em relações de causalidade. Enquanto um fenômeno envolve também questões subjetivas considerando que a construção de conhecimento se dá no encontro sujeito-objeto. Dessa forma, é fundamental que algo se mostre oculto ao pesquisador. Pedindo por um desvelamento, um aclareamento. Essa idéia refere-se à questão da intencionalidade:

[...] o princípio da intencionalidade é que a consciência é sempre consciência de alguma coisa, que ela só é consciência estando dirigida para um objeto. Por sua vez, o objeto só pode ser definido em sua relação com a consciência, ele é sempre objeto-para-umsujeito [...] (Dartigues, 1973: 24). 
Esse autor complementa que, nesse processo, o objeto não está contido na consciência, não se tratando de duas entidades separadas, mas parte de uma relação na qual um não existiria sem o outro.

Essa perspectiva de abordagem tornou-se muito significativa para nós. À medida que diferentes formas de aproximações foram ocorrendo relacionadas com o tema integralidade. Em nossa trajetória no campo de pesquisa nosso olhar dirigiu-se para a experiência de agentes sociais na atenção psicossocial ao adolescente, numa rede de proteção social à criança e ao adolescente que está se constituindo no município de Suzano, São Paulo; como relataremos à frente quando descrevermos o cenário de estudo.

Vários questionamentos foram se acumulando em campo de pesquisa ao longo do tempo. Eis alguns: Como os agentes sociais vivenciam a atenção ao adolescente? Quais as implicações de seu cotidiano? Como os paradigmas de saúde se mostram a eles? Qual sua compreensão do fenômeno saúde-doença na adolescência? Haveria uma tentativa de atenção integral?

Essas inquietações trouxeram a reflexão sobre a dimensão existencial desses agentes, em seu trabalho no campo da saúde, muitas vezes caracterizada por práticas mecanizadas e tecnicistas. Em um cenário no qual os avanços tecnológicos e científicos evoluem com velocidade espantosa costumamos ouvir manifestações preocupadas com a situação da saúde na sociedade. 
Preocupações certamente relacionadas com uma maior transparência, advinda dos meios de comunicação, que deixam aflorar comportamentos insalubres e descobertas no campo da saúde que antes permaneciam despercebidos; e, com a gravidade das consequências que esses comportamentos e descobertas podem acarretar, devido tanto ao fator potencializador dos atuais recursos científico-tecnológicos - como a agressão ao meio ambiente ou a manipulação genética-, quanto à sua capacidade de manejar domínios fundamentais da existência humana - como a interrupção ou prolongamento da vida ou a pesquisa com células-tronco embrionárias. Estas possibilidades geram uma preocupação de dimensões talvez nunca antes registradas nos mais diferentes domínios do conhecimento e das atividades humanas. A busca quase febril por modelos de comportamentos saudáveis, que possibilitem melhor qualidade de vida e seu prolongamento, esbarra na redução da vida à sua dimensão biológica, na primazia dos interesses de observação e controle de padrões fisiológicos pela ciência no campo da saúde (Lipovetsky, 2004; Goergen, 2005).

Nesse contexto, o olhar fenomenológico pôde permitir o acesso à subjetividade, da experiência vivida. Da dimensão humana que não se reduz ao aspecto biológico, mas, o incorpora em articulação com o psicológico, social e cultural, ou seja, considerando o sujeito em sua integralidade, em sua dimensão existencial. Compreendemos que o foco do nosso questionamento referia-se a integralidade. Referia-se a compreensão sobre: Qual a noção de integralidade presente na prática dos agentes sociais na atenção à saúde do adolescente?

Foi necessário considerar que a prática em saúde não é uma realidade em si mesma, pré dada, na qual o profissional se insere somente para cumprir rotinas. Ela é 
constituída pelos sujeitos que ali atuam e, de algum modo, se vinculam, estando alicerçada em uma concepção de homem e de mundo que pode e precisa ser questionada.

[...] investigar é sempre colocar em andamento uma interrogação. É perguntar. Não se sai em busca de compreensão de um fenômeno tentando aplicar sobre ele uma resposta já sabida sobre ele mesmo. Investigar não é assim, uma aplicação sobre o real do que já se sabe a seu respeito. Ao contrário, é a ele que perguntamos o que queremos saber dele mesmo. (Critelli, 1996: 25)

Qualquer investigação constitui-se por interrogar pelo ser de algo. A partir da compreensão do ser é que se determina a estrutura da interrogação. Para a fenomenologia, a questão do ser apresenta-se de forma própria e verdadeira, no movimento do existir e vir a ser no mundo, diferente do pensar metafísico que concebe o ser e o mundo como entidades isoladas (Critelli, 1996).

A característica da fenomenologia está em voltar às coisas nelas mesmas, na tentativa de aproximação às coisas sem preconceitos ou pressupostos interpretativos (Capalbo, 1984). O acesso à compreensão dos agentes sociais sobre a integralidade implicou em que nosso olhar se voltasse para a análise do vivido tal como ele é experienciado. Não se trata de saber sobre o fenômeno integralidade, mas, sim do fenômeno da integralidade tal como ele emerge, como ele se mostra, no discurso dos agentes sociais em sua especificidade.

Desse modo a nossa preocupação não se limita ao fato da integralidade na prática em saúde, mas, envolve o fenômeno de compreensão da integralidade. A compreensão parte do princípio de que os fenômenos humanos possuem, em sua base, características de sentidos e significados, divergindo da lógica das ciências naturais que 
os vê como algo regido pelas reações explicativo-causais (Valle, 1997). Assim, uma vez que os fenômenos humanos, comportando a dimensão existencial, diferenciando-se por essência de um fenômeno puramente objetivo, devem, então, ser interpretados segundo as ciências humanas, como um saber do homem sobre o homem (Dartigues, 1973).

Ao compreender um fenômeno é preciso levar em conta que ele não possui apenas um sentido. É preciso partir de uma pré-compreensão oriunda da experiência vivida. Algo é compreendido em vista de uma totalidade - não de forma isolada. Sendo considerado seu contexto, toda compreensão é histórica, para cada momento vivido existe uma compreensão que se relaciona e se funda em outras compreensões e, por fim, toda compreensão é auto-compreensão. Pois todo ser humano que compreende o outro passa a compreender-se cada vez mais a si mesmo.

A compreensão é um acontecimento tão fundamental quanto universal. Ao estar relacionada a uma palavra falada ou escrita, testemunhos ou fatos históricos realiza-se no todo de nosso mundo permanecendo como possibilidade no horizonte de nossas relações (Coreth, 1973). Sobre esse aspecto Valle (1997) complementa, então que para que o processo de compreensão ocorra é necessário reconstruir o mundo do sujeito, nele penetrar, ouvir sobre suas experiências a fim de apresentar a sua forma de experienciar o mundo.

Tendo em vista a intenção, o foco deste estudo, cabe ressaltar que a postura do pesquisador diverge da neutralidade requerida pela pesquisa científica clássica. Essa postura, na abordagem fenomenológica, deixa de ser distante, objetiva e 
despersonalizada. "Não considera diante de si o ser humano apenas como seu objeto de pesquisa, mas um sujeito que tem seu mundo a ser desvelado" (Valle, 1997: 47). Assim, nossa presença não foi apenas física, nela esteve implícito o significado humano. Essa relação de sujeito-mundo permeou todos os momentos da investigação. 


\section{Hipótese}

As diversas influências teóricas sobre o entendimento do fenômeno integralidade resultaram no aparecimento de grande diversidade de olhares sobre possíveis concepções de atenção integral ao adolescente no campo da saúde. E tornaram complexas a organização de um sistema de atenção à saúde integral do adolescente. $\mathrm{O}$ caráter eminentemente multiprofissional desta atividade, bem como o discurso médico comumente aceito, e incorporado pelas famílias, também contribuem para torná-lo mais complexo.

Quando nos referimos a uma compreensão de integralidade na atenção psicossocial do adolescente, a tomamos como parte integrante da assistência integral à saúde do adolescente, constituindo um desafio de apreensão/compreensão dessa problemática na organização do atendimento cotidiano. A identificação desse conceito de integralidade incide diretamente sobre a seleção dos problemas prioritários a serem enfrentados, aos planejamentos terapêuticos racionalmente efetuados e à organização de serviços que permitam, numa rede de proteção social, tornar concretas as questões relativas à operacionalização do atendimento ao adolescente.

Diante dos desafios/dificuldades de uma compreensão sobre a integralidade, numa abordagem do fenômeno adolescente, que apreenda uma atenção psicossocial. Temos como pressuposto básico que as experiências existentes na cidade de Suzano, na rede de proteção à criança e ao adolescente, permitam contribuir para a reflexão e o repensar a noção de integralidade na atenção psicossocial do adolescente. 


\section{Objetivos}

1) Compreender a noção de integralidade emergente em uma Rede de Proteção Social à Criança e ao Adolescente.

2) Caracterizar o lugar da integralidade no interior dessa rede de serviços e sua contribuição em uma abordagem de atenção psicossocial ao adolescente.

3) Refletir sobre essa noção de integralidade na perspectiva de algumas circunstâncias que a inserem na sociedade contemporânea . 


\section{O cenário de pesquisa}

O Conselho Municipal de Defesa dos Direitos da Criança e do Adolescente Comdicas -, elaborou o Plano Municipal para a Criança e o Adolescente de Suzano (2006/2007), em seu texto introdutório apresenta uma caracterização sócio-econômica da cidade. Consideramos que este texto apresenta o olhar do conselho sobre o município e assim, o tomamos para este fim.

Suzano é um dos trinta e nove municípios que compõem a Região Metropolitana de São Paulo. Está situado na sub-região leste, distante quarenta e dois quilômetros da capital paulista, com área territorial de $206 \mathrm{~km} 2$. Suzano é uma cidade jovem emancipada politicamente há 50 anos, com população de mais de 270 mil habitantes, com crescimento médio populacional de 3,49\%. Faz divisa como Itaquaquecetuba ao norte, Mogi das Cruzes a leste, Santo André ao sul, Rio Grande da Serra e Ribeirão Pires a sudoeste, Mauá e Ferraz de Vasconcelos a oeste e Poá a noroeste.

O município se caracteriza pela ocupação esparsa de seu território, o que dificulta o acesso a terra e à moradia pela população de baixa renda. Isso tem impulsionado a ocupação em áreas vulneráveis, como as áreas de proteção ambiental, de risco aos mananciais, gerando um crescimento desordenado da cidade.

Em relação à atividade econômica, o município caracteriza-se pela forte presença dos setores comercial e industrial, de prestação de serviços e de produção agrícola. São 327 indústrias, 3423 estabelecimentos comerciais, 744 estabelecimentos de serviços e outros 45 tipos de estabelecimentos. Das 24 grandes empresas que 
existem na região, 12 estão instaladas no município. Apesar de estes números serem significantes muitos susanenses não compõe esta força de trabalho.

O sistema educacional abrange a Educação Infantil, Ensino Fundamental, Ensino Médio, Educação de Jovens e Adultos (EJA) e o Ensino Universitário, este último, executado somente pelo setor privado. Da proporção da população que freqüenta a escola, conforme dados mais recentes do IBGE, na faixa de 0 a 6 anos, são $24,5 \%$, de 7 a 14 anos, $96,2 \%$ e de 15 a 17 anos, $83,4 \%$. O texto do Comdicas define a freqüência e não a análise da qualidade do ensino.

O sistema de saúde no município conta com a execução de serviços tanto públicos como privados. Há 14 Unidades Básicas de Saúde - UBS, distribuídas entre os diversos bairros. Existe ainda, um Ambulatório de Especialidades e um Ambulatório de Saúde Mental. Está-se implantando o Programa Saúde da Família - PSF. Foram criados recentemente o Centro de Apoio Psicossocial - Caps, a Farmácia Popular e o Centro de Especialidades Odontológicas - CEO. O Pronto Socorro Municipal e o Pronto Atendimento Municipal do bairro de Palmeiras oferecem atendimento emergencial. A Santa Casa de Misericórdia é o único serviço credenciado pelo SUS para atendimento de alta complexidade, a qual não comporta a demanda do município, obrigando os usuários a procurarem atendimento que requer internação em outras cidades da região. No índice de mortalidade infantil houve uma queda em relação aos anos anteriores de 23 para 13,9 por mil nascidos vivos.

A política social do município iniciou um processo de descentralização dos serviços por meio dos Centros de Referência de Assistência Social - Cras, vinculados 
ao Programa de Atenção Integral à Família - Paif, do Governo Federal. Há quatro Cras no município localizados nos distritos dos bairros Boa Vista, Palmeiras, Centro e na região do bairro da Casa Branca. Foi criado recentemente o Centro de Atenção Integral à Criança e ao Adolescente - Caica, que desenvolve atendimento para crianças em situação de rua. A este serviço foram incorporadas duas unidade de abrigamrento existentes anteriormente.

As atividades culturais de Suzano são realizadas no Centro de Educação e Cultura Francisco Moriconi, no Auditório Municipal Dr. Armando de Ré, Casarão das Artes, Galpão das Artes e no Centro Cultural de Palmeiras. Em todos os equipamentos são oferecidas atividades gratuitas. Os serviços ainda estão centralizados e as vagas disponíveis concorridas. Algumas parcerias com entidades culturais têm viabilizado um pouco o acesso a oficinas culturais.

As atividades esportivas são realizadas no Ginásio de Esporte Paulo Portela, localizado na região central, no Ginásio Municipal de Esportes Professor Roberto David, no bairro do Sesc e no Estádio Municipal Francisco Marques Figueira, na região do Jardim Colorado. O Programa de Esportes Educacionais Direcionados - Peed, realizado em parceria com entidades, procura tornar acessível o atendimento nos bairros periféricos.

O município conta com um Conselho Tutelar e outros conselhos voltados para elaboração de políticas para crianças e adolescentes: Conselho Municipal dos Direitos da Criança e do Adolescente, Conselho Municipal de Assistência Social, Conselho 
Municipal de Educação, Conselho Municipal de Cultura, Conselho Municipal de Esportes e Conselho Municipal de Saúde. 


\section{Seleção dos sujeitos de pesquisa}

Para a efetivação da lei da Lei 8.069/90, em que se estabeleceu o ECA, foram criados instrumento para a efetiva implantação e implementação na esfera Municipal, o Conselho Tutelar, o Conselho Municipal dos Direitos da Criança e do Adolescente e o Fundo Municipal. É no município que a percepção das mais diversas situações que caracterizam a violação de direitos, tornam-se visíveis e compreensíveis.

De acordo com o ECA (artigos 88, 214 e 260), o Conselho de Direitos da Criança e do Adolescente é um órgão ou instância colegiada de caráter deliberativo, formulador e normatizador das políticas públicas, controlador das ações, gestor do Fundo, legítimo, de composição paritária e articulador das iniciativas de proteção e defesa dos direitos da criança e do adolescente. Integra a estrutura básica do poder executivo, da secretária de promoção social e tem composição e organização fixadas por lei.

O Conselho de Direitos da Criança e do Adolescente, conhecido em Suzano como Comdicas, tem competência para exercer o controle das ações de todos os direitos à criança e ao adolescente de forma global. Crianças e adolescentes não são uma área - são um público que deve ter prioridade absoluta em todas as áreas (saúde, educação, assistência social, cultura, esporte...). Por isso se diz que é um conselho público e de política, inter e multi setorial. Entre várias competências podemos destacar as seguintes: coordenação da eleição do Conselho Tutelar; gestão do Fundo por meio de uma Junta, Secretaria de Governo ou Administrador; registro das entidades e inscrição dos programas de atendimento de crianças e adolescentes; elaboração do plano de ação 
e do plano de aplicação; montagem da proposta orçamentária do Fundo; constituição de comissões; edição de resoluções e constituição de Secretaria Executiva.

O Município de Suzano, por apresentar em sua política pública um serviço de atenção ao adolescente numa rede de proteção social, apresentou-se como uma seara propícia para o estudo desta pesquisa. Era comum ouvirmos de agentes sociais, de líderes comunitários e profissionais do serviço de saúde falas que objetivavam "atender o adolescente como um todo”, ao nosso ver, discursos que sinalizavam a preocupação com a integralidade. Porém, ao entrar em contato com a Secretaria Municipal de Saúde, em sua rede de atendimento, percebemos que a presença do adolescente era restrita ao atendimento médico ou à participação no CTA - Aids. Fato que nos levou ao questionamento sobre a validade de nossa pesquisa se situar nesse campo. Foi nesse momento que tivemos a oportunidade de conhecer o trabalho da rede de proteção social acompanhada pelo Comdicas.

O Comdicas ao congregar pessoas do poder público e da sociedade civil para fiscalizar, deliberar e encaminhar políticas públicas destinadas a criança e ao adolescente. É constituído por representantes do serviço público das secretarias de saúde, educação, esporte, cidadania, enre outros; e, entidades sociais responsáveis pela atenção à criança e ao adolescente. Os atores sociais envolvidos no conselho e que compõem uma rede proteção social ao adolescente, também apresentavam essas falas que objetivavam "atender o adolescente como um todo", sinalizando para uma preocupação com a integralidade. Devido, inclusive, ao Poder Público Municipal estar em processo de implementação de novas inciativas de atenção ao adolescente. Assim, 
em contato prévio com alguns informantes ficou claro que nossa preocupação seria bem recebida por esta instituição que queríamos ter como parceira de pesquisa.

A escolha desta instituição pareceu-nos preencher o critério de representatividade do contexto onde queríamos realizar a pesquisa. Isto significou que as pessoas que compunham esse grupo seriam significativas para nos fornecer informações que julgávamos necessárias à pesquisa do tema proposto. Assim, ao participarmos em uma das reuniões do Conselho, no início do ano de dois mil e seis, apresentamos nossa proposta de pesquisa. A qual foi prontamente aceita pelo grupo. 


\section{O acesso aos sujeitos de pesquisa}

Entretanto, no início da incursão no campo de pesquisa, o desafio ao acolhimento do outro, de estar aberto para a escuta, de navegar pelo discurso, foi imenso. Foi se mostrando na vivência do pesquisador que se aproxima da abordagem fenomenológica, a necessidade de estar disposto a apreender e permitir o mostrar-se da experiência vivida pelo outro, em suas falas, gestos, posturas, silêncios, reticências. Tratou-se de um processo de desconstrução pessoal, não apenas do pesquisador, mas também, do informante. Pois estamos acostumados, pesquisador e sujeito de pesquisa, a uma tradição de pesquisa composta de perguntas, alternativas e respostas. A surpresa do informante com a possibilidade de discursar sobre sua experiência vivida, relatar livremente sobre o tema proposto, a princípio gerou inquietação que logo foi substituída por espontaneidade.

Amatuzzi (2001) contribuiu com esse momento ao dizer que na pesquisa fenomenológica, 'lemos o vivido’ entrando em contato com suas manifestações e estas se dão por meio de pensamentos e ações, sendo qualquer forma de expressão humana constituída em depoimento. O que importa é sob qual luz lemos essa expressão, no sentido de penetrar a materialidade do depoimento, seguindo em direção ao vivido e expressando-o em um outro pensamento que faça sentido no contexto da temática enfocada pelo pesquisador.

Carvalho (1987) enfatiza que o sujeito de pesquisa não é um ator que representa um personagem no palco. O sujeito vive a sua história e imprime todo o seu passado e seu futuro no presente. Seus gestos, movimentos, olhares, entonação de voz, silêncio são 
formas de vivenciar o mundo que o sujeito expressa e que têm íntima relação com as faces desveladas do fenômeno em questão. Foi desafiador para o pesquisador desenvolver certa intuição e sensibilidade para perceber e captar esses momentos.

Desta forma perceber esses gestos e momentos em seus movimentos significou captar uma expressão de sentido, reconhecendo o sujeito, relacionando-o ao seu engajamento no mundo natural e social, considerando a sua história. Percebendo, assim, que o sujeito de pesquisa não se dissocia de uma situação, de sua circunstância. Em seus gestos e nos momentos de entrevista, na verdade, foi uma situação/contexto que se mostrou e que se desvelou.

Nesse processo aproximamo-nos do cenário de estudo habitando esse mundo. Estivemos presentes nesses cenários nos quais cada sujeito entrevistado trazia um mundo diferenciado. Principalmente no sentido de captar o que se mostrava na relação do sujeito com o objeto de pesquisa. Acompanhando os sujeitos em diversos momentos buscamos dirigir nosso olhar para essas relações. Nas sucessivas aproximações buscamos construir vínculos de confiança que poderiam nos garantir a efetividade das entrevistas.

Pareceu-nos, realmente, existir um período de adaptação entre pesquisador, sujeitos e objeto de pesquisa. É importante reconhecer que um considerável desafio foi vivenciado pelo pesquisador ao abordar o tema integralidade. Nos primeiros momentos exigiu maiores recursos próprios de sua formação em psicologia no sentido de dialogar, respeitando as singularidades dos sujeitos, suas expectativas e histórias de vida. Bem como um aprofundamento teórico e desempenho na relação com o campo da Saúde 
Pública. Ocorreu que, ao tratar da integralidade, como será melhor detalhado no tratamento dos dados, o pesquisador encontrou-se com reflexões de abordagem integral do tema em foco. Situação que colaborou para ampliar a vivência do tema, mas, também, para analisar as circunstâncias que o limitam ou o expandem. Isto se mostrou extremamente complexo e, na busca de assegurar o rigor metodológico, foi necessário conceder o tempo necessário que facilitasse esse período de adaptação, reflexão e análise. 


\section{Coleta dos dados:}

\section{- Pesquisa qualitativa -}

\section{observação participante e entrevista semiestruturada}

Utilizamos a abordagem qualitativa por apresentar-se metodologicamente adequada aos nossos objetivos e ao caráter fenomenológico desta pesquisa, enquanto orientação ao procedimento de delinear olhares aos elementos teóricos que envolvem as narrativas sobre a integralidade, e como essas narrativas se traduzem no cotidiano dos atores sociais envolvidos nesse processo.

A pesquisa qualitativa se processou com a utilização de duas estratégias. O mais importante foi recolher "com pertinência os dados necessários, sem preocupações com a definição de uma amostra estatística, pois o que buscávamos era a compreensão do significado e as relações expressadas pelos atores sociais” (Minayo, 1992: 11-18)

\begin{tabular}{|c|c|c|}
\hline \multicolumn{3}{|c|}{ ESTRATÉGIAS E INSTRUMENTOS PARA COLETA DE DADOS } \\
\hline TIPO & DESCRIÇÃO & USO \\
\hline \begin{tabular}{|l} 
OBSERVAÇÃO \\
PARTICIPANTE
\end{tabular} & $\mid \begin{array}{l}\text { O pesquisador participou nas reuniões do } \\
\text { Comdicas, observando, no conjunto de } \\
\text { operações dos atores sociais, as falas relativas } \\
\text { ao tema proposto agregando informações à } \\
\text { coleta de dados em preparação às entrevistas } \\
\text { semi-estruturadas. }\end{array}$ & $\begin{array}{l}\text { A observação ocorreu sobre os indicadores } \\
\text { selecionados: integralidade, adolescência, } \\
\text { atenção psicossocial. O pesquisador } \\
\text { procedeu pessoalmente a estas observações. } \\
\text { Constituindo um diário de campo como } \\
\text { instrumento de registro. }\end{array}$ \\
\hline $\begin{array}{l}\text { ENTREVISTA } \\
\text { SEMI- } \\
\text { ESTRUTURADA }\end{array}$ & $\mid \begin{array}{l}\text { A entrevista semi-estruturada por não } \\
\text { apresentar-se inteiramente aberta e não ser } \\
\text { conduzida por muitas questões pré- } \\
\text { estabelecidas (baseia-se apenas em uma ou } \\
\text { poucas questões/guias). Possibilitou, durante a } \\
\text { realização da entrevista, a introdução de outras } \\
\text { questões que surgiram de acordo com o que } \\
\text { emergia no processo - em relação às } \\
\text { informações que desejávamos obter. }\end{array}$ & $\begin{array}{l}\text { Foram realizadas entrevistas com seis } \\
\text { participantes indicados pelo Conselho. Que } \\
\text { apresentaram relevância conceitual, } \\
\text { atitudinal e procedimental em seus } \\
\text { discursos, se destacaram na observação } \\
\text { participante e nas discussões em grupo, } \\
\text { como lideranças no atendimento ao } \\
\text { adolescente. }\end{array}$ \\
\hline
\end{tabular}


$\mathrm{Na}$ coleta dos dados qualitativos a representatividade do fenômeno a ser estudado procede por meio de informantes selecionados intencionalmente e de acordo com os objetivos propostos. A rigor, não existe necessidade de definir uma amostra, porque o importante é o significado de uma informação para a situação estudada e não a quantidade de informantes que repetem essa mesma informação ou o número de vezes em que ela aparece (Minayo, 1992).

Escolhemos duas estratégias qualitativas, quais sejam, a Observação Participante e Entrevistas Semi-estruturadas que nos pareceram adequadas como "exercício reflexivo de apreensão de uma dada realidade, ou como expressão da relação sujeito/objeto" (Adorno 1994: 173). O método proposto foi entendido como o uso combinado de duas diferentes técnicas de coleta de dados para envolver o processo de modo a maximizar a validade da pesquisa. Segundo Spink, na medida em que se torna mais claro que cada método configura o objeto de uma forma específica, o sentido de utilizar diferenciadas estratégias foi se modificando, abandonando-se a referência à validação a favor do enriquecimento da interpretação. As estratégias utilizadas permitiriam levantar e compilar uma grande quantidade de informação. No entanto, foi necessário adequar os instrumentos de pesquisa para definir com clareza o conteúdo mais específico a ser coletado.

Minayo (1992: 135) considera a observação participante “(...) parte essencial do trabalho de campo na pesquisa qualitativa. Sua importância é de tal ordem que alguns estudiosos a tomam não apenas como uma estratégia no conjunto da investigação, mas como um método em si mesmo, para compreensão da realidade”. A observação participante caracterizou-se, assim, por um processo em que o observador 
manteve-se presente na situação social estudada com o objetivo de realizar uma investigação científica. A interação com os atores sociais, a participação em seu cenário cultural, a inserção em seu contexto social possibilitaram maior empatia no processo de pesquisa e melhor compreensão do tema objeto de estudo.

A observação participante surgiu como estratégia de pesquisa no trabalho de campo da Antropologia, com Malinowski , em 1922; como "forma complementar de captação da realidade empírica". E, desde então, "amplamente utilizada, problematizada e referendada como contribuição específica para a construção de conhecimento” (Minayo, 1992:135-156).

Utilizamos a observação participante, como estratégia de abordagem junto aos sujeitos de pesquisa, definindo previamente os aspectos, fatos e elementos do ambiente considerados fundamentais para o processo de pesquisa. Registrando as narrativas pessoais e o modo como os informantes reagiam - seus gestos, atitudes, comportamento físico e emocional -, como também todas as circunstâncias consideradas importantes e que envolviam o fato/fenômeno que nos propomos observar (Minayo, 1992).

No prosseguimento nos propusemos a realizar entrevistas semi-estruturadas com membros do Comdicas que apresentassem relevância conceitual, atitudinal e procedimental em suas narrativas e que se destacassem, na discussão do Conselho, como lideranças no atendimento ao adolescente. O pesquisador teve a oportunidade de participar em reunião e apresentar sua proposta de pesquisa e estratégia de entrevista para os conselheiros. Estes, após aprofundamento, indicaram seis conselheiros - três do 
poder público e três da sociedade civil -, assim, contribuindo com maior vitalidade aos objetivos da pesquisa. Pareceu-nos oportuna a indicação desses seis conselheiros por possibilitar-nos a ampliação das narrativas e diferentes análises, visto que o conselho era composto por dezoito membros.

Minayo (1992: 107-125), descreve e problematiza a entrevista como "o recurso mais utilizado no processo de trabalho de campo". Discute sua validade e suas contradições. A entrevista semi-estruturada em suas diversas modalidades apresenta-se como fonte de informação, de acesso à polifonia dos informantes, não apenas restringindo-se à fala dos entrevistados, mas, a todo o contexto que corrobora para determinada cosmovisão. "Devemos nos privar de certa ingenuidade metodológica que procura nos convencer da imparcialidade da pesquisa científica para nos abrirmos a uma concepção crítica”. Percebendo que, “na interação pesquisador/informante, se dá uma cumplicidade" que necessita ser desvelada para garantir a fidedignidade do processo.

Assim, acreditamos que a entrevista semi-estruturada concluiu o processo de observação participante contribuindo para coleta de narrativas nas quais:

\footnotetext{
“(....) os modelos culturais interiorizados reflitam o caráter histórico e específico das relações sociais. Desta forma os depoimentos têm que ser colocados num contexto de classe, mas também de pertinência a uma geração, a um sexo, a filiações diferenciadas. E porque cada ator social se caracteriza por sua participação, no seu tempo histórico, num certo número de grupos sociais, informa sobre uma 'subcultura' que lhe é específica e tem relações diferenciadas com a cultura dominante.” (p. 113)
}

A entrevista semi-estruturada por não apresentar-se inteiramente aberta e não ser conduzida por muitas questões pré estabelecidas possibilitou-nos, durante a realização 
da entrevista, a introdução de outras questões que surgiram de acordo com o que acontecia no processo em relação às informações que desejávamos obter.

Desta forma, ao utilizarmos esses recursos para acessarmos as narrativas sobre a integralidade, no contexto de uma rede de proteção social ao adolescente, temos que a observação participante constituiu o paradigma de acesso ao cenário e à atuação dos sujeitos de pesquisa. Enquanto as entrevistas, no bojo da observação participante, socializaram as narrativas trazendo a oportunidade do diálogo, da exposição de cosmovisões e da reflexão; bem como, os aprofundamentos de questões relevantes que emergiram e mereceram ser destacadas no âmbito da fenomenologia dos discursos. O que tornou esse processo uma estratégia privilegiada de coleta das narrativas. Pois, “ $a$ possibilidade de a fala ser reveladora de condições estruturais, de sistemas de valores, normas e símbolos (sendo ela mesma um deles) e ao mesmo tempo ter a magia de transmitir, através de um porta-voz, as representações de grupos determinados, em condições históricas, sócio-econômicas e culturais específicas" (Minayo, 1992:109110) contribuiu para desvelar o fenômeno em foco no relato das experiências de uma entrevista que permitiu o diálogo com os entrevistados.

\footnotetext{
"Em uma entrevista fundamentada na metodologia fenomenológica, não se busca uma linguagem que seja a soma de pensamentos e idéias. Busca-se uma linguagem que seja fala originária, fala essa que possibilite a mediação com o outro e a comunicação com o mundo." (CARVALHO, 1987: 37)
}

Assim, para Martins e Bicudo (1989), a entrevista semi-estruturada é considerada, na abordagem fenomenológica, com características peculiares como a empatia e a intersubjetividade, corroborando a uma inter-relação mútua de percepções. 
A questão norteadora, nesta pesquisa, referiu-se ao relato da experiência do entrevistado em sua atuação como agente formador de opinião, conselheiro de direito e representante de entidade social. A questão eliciadora da narrativa iniciava com: Me fale sobre sua atuação na entidade social que você representa no conselho de direitos. Descreva como se dá a atenção ao adolescente. Se no discorrer dessas questões não ficasse claro, ou mesmo, não emergisse a temática da integralidade a pergunta: $O$ que você conhece sobre integralidade na atenção ao adolescente?; era um recurso utilizado para que o informante pudesse relatar sobre o tema. Cabe ressaltar que, a partir dessas questões, foi se configurando um diálogo que permitiu a livre expressão do sujeito de pesquisa, com foco na sua experiência vivida naquele momento.

A observação participante ocorreu durante todo o ano de dois mil e seis e configurou-se pela aproximação do pesquisador às reuniões ordinárias do Comdicas, participação nas audiências públicas, visitas às entidades sociais conveniadas. Acesso aos sujeitos de pesquisa em situações corriqueiras como o café entre as reuniões, conversas espontâneas antes e após reuniões, o encontro em outras instâncias municipais, o convite a participar em eventos nas entidades sociais.

As entrevistas foram coletadas no período de junho a setembro de dois mil e seis. Mostraram-se reveladoras para a compreensão do fenômeno pesquisado. Reveladoras no sentido de lançarem luz ao fenômeno, desvelando algumas de suas facetas, o que envolve o emergir de pontos convergentes e divergentes em cada entrevista e na articulação entre elas. 
Cabe salientar que o desvelamento de um fenômeno nunca é total, pois sempre surgirão novos velamentos a partir de novas inquietações do investigador. Boemer (1994) menciona que os significados expressos nas falas estão inseridos em uma totalidade que vai além da explicada pelo sujeito, havendo sempre uma região não expressa que permanece oculta. Dessa forma a pesquisa sempre prossegue.

Para a realização da pesquisa utilizamos o gravador de voz modelo MP3. As entrevistas ocorreram em visitas agendadas na sede da entidade social ou secretaria na qual o entrevistado desenvolve suas atividades.

Ao apresentar a proposta de estudo aos entrevistados, especificamente, a integralidade nos cenários da rede de proteção social ao adolescente, foi assegurado o sigilo dos depoimentos, a possibilidade de recusa, bem como a intencionalidade de divulgação e publicidade dos dados no âmbito acadêmico e público. Procedeu-se a assinatura do Termo de Consentimento Livre e Esclarecido, conforme os princípios fundamentais da Ética em Pesquisa. 


\section{Sistematização dos dados coletados}

Para realizar uma compreensão adequada das narrativas, no contexto da pesquisa qualitativa, numa abordagem fenomenológica, recorremos à análise de conteúdo que "oferece a possibilidade de tratar de forma metódica informações e testemunhos que apresentam certo grau de profundidade e de complexidade” (Quivy, 2003:227). O recurso da síntese categorial possibilitou a compreensão das práticas discursivas dos entrevistados a partir dos parâmetros propostos pelos objetivos desta pesquisa.

Spink conceitua categoria como constituinte própria da organização da linguagem utilizada, no cotidiano das pessoas, para a compreensão do mundo:

“(....) as categorias constituem importante estratégias lingüísticas expressas por meio de práticas discursivas delineadas para conversar, explicar, organizar e dar sentido ao mundo, cujas especificidades estão vinculadas ao contexto que as produzem (....) as categorias como estratégias lingüísticas estão presentes na própria organização da linguagem (verbal, escrita, gestual, icônica). Utilizamos categorias para organizar, classificar e explicar o mundo." (1999: 79) 


\begin{tabular}{|c|c|c|c|c|c|}
\hline \multicolumn{6}{|c|}{ QUADRO ESQUEMÁTICO PARA COLETA DAS NARRATIVAS } \\
\hline TEMÁTICA & Sujeito de pesquisa & FONTE & PARÂMETROS & $\begin{array}{l}\text { PREPARO DOS } \\
\text { DADOS PARA } \\
\text { ANÁLISE }\end{array}$ & $\begin{array}{l}\text { TIPO DE } \\
\text { ANÁLISE }\end{array}$ \\
\hline \begin{tabular}{|l||} 
Como \\
acontece na \\
Rede de \\
proteção ao \\
adolescente a \\
integralidade \\
numa \\
perspectiva de \\
atenção \\
psicossocial.
\end{tabular} & $\begin{array}{l}\text { Opinião de seis } \\
\text { membros do } \\
\text { Comdicas, três } \\
\text { membros da } \\
\text { sociedade civil e } \\
\text { três membros do } \\
\text { poder público. } \\
\text { Indicados pelo } \\
\text { Conselho, e, que se } \\
\text { destacaram na } \\
\text { observação } \\
\text { participante como } \\
\text { lideranças no } \\
\text { atendimento ao } \\
\text { adolescente. } \\
\text { Apresentando } \\
\text { relevância } \\
\text { conceitual, } \\
\text { atitudinal e } \\
\text { procedimental em } \\
\text { suas narrativas. }\end{array}$ & \begin{tabular}{|l} 
ENTREVIS- \\
TAS SEMI- \\
ESTRUTURA- \\
DAS
\end{tabular} & $\begin{array}{l}\text { Conhecimento sobre } \\
\text { objetivos, metas e atividades } \\
\text { desenvolvidas pela Rede de } \\
\text { Proteção social ao } \\
\text { adolescente; } \\
\text { Relato do envolvimento do } \\
\text { participante na Rede de } \\
\text { Proteção Social ao } \\
\text { adolescente; } \\
\text { Quais os principais } \\
\text { encaminhamentos e decisões } \\
\text { compartilhadas entre os } \\
\text { membros do Conselho } \\
\text { referentes a integralidade } \\
\text { como atenção psicossocial }\end{array}$ & \begin{tabular}{|l} 
Transcrição das \\
narrativas \\
obtidas; \\
Ordenação dos \\
dados obtidos \\
através de \\
definição prévia \\
de categorias \\
relacionadas \\
com os \\
parâmetros; \\
Classificação \\
dos dados \\
obtidos por meio \\
de aspectos \\
sobre os quais se \\
analisou o \\
conteúdo; \\
Análise com \\
base em \\
categorias \\
(núcleos \\
temáticos)
\end{tabular} & $\begin{array}{l}\text { Qualitativa } \\
\text { numa } \\
\text { abordagem } \\
\text { Fenômeno- } \\
\text { lógica }\end{array}$ \\
\hline
\end{tabular}


A análise do conteúdo, a partir do recurso de disposição categorial das práticas discursivas, se adequou ao estudo do não dito, do implícito nas narrativas apreendidas ao longo do processo de interação entre o pesquisador e os sujeitos de pesquisa. Instrumentalizando-o a distanciar-se de interpretações espontâneas, em particular às suas próprias, para uma análise a partir de critérios que incidem mais sobre a organização interna do discurso que sobre o seu conteúdo explícito (Minayo, 1992; Spink, 1999; Quivy, 2003).

Tomando como pressuposto que as falas e as interações lingüísticas empregam descrições categoriais de maneira reflexiva e em conformidade com o contexto interacional, as narrativas colhidas durante o processo com os sujeitos de pesquisa, carregou a possibilidade de expor significados e compreensões distintas vinculadas à história de sua construção.

Por isso, "as categorias não têm um valor ou sentido que lhes seja intrínseco" (Spink, 1999:83). Antes, necessitam de parâmetros para que sejam explicitadas para o processo de análise. 


\section{Categorização das entrevistas}

Com o intuito de facilitar a compreensão dos relatos, em seu contexto, apresentamos a seguir os entrevistados com as iniciais de seus nomes e a sistematização de seus relatos por categorias emergentes do discurso.

1) Entrevista número um realizada em sete de junho de dois mil e seis.

Dados da entrevistada: MC; 45 anos; solteira; psicóloga com especialização em Psicologia Social; residente no município de Suzano; Coordenadora do Caica.

Dados do trabalho desenvolvido pela entrevistada: MC, formada em psicologia, militante em defesa dos direitos da criança e do adolescente foi eleita como conselheira no primeiro Conselho Tutelar de Suzano responsável em organizar o regimento e a implantação desse órgão na cidade. Coordena o Centro de Atenção Integral à Criança e ao Adolescente - Caica. O Caica é um órgão público municipal responsável pela gestão da política municipal do abrigamento de crianças e adolescentes encaminhados pelo Conselho Tutelar, pela Vara da Infância e Juventude, entre outros. Composto pela Casa de Passagem e duas casas de abrigo, quais sejam, a Casa da Criança e a Casa do Adolescente. 


\section{SISTEMATIZAÇÃO DA NARRATIVA}

FONTE: entrevista semi-estruturada

SUJEITO DE PEQUISA:

MC; 45 anos; psicóloga com especialização em Psicologia Social; Coordenadora do Caica responsável pela gestão da política municipal do abrigamento de crianças e adolescentes.

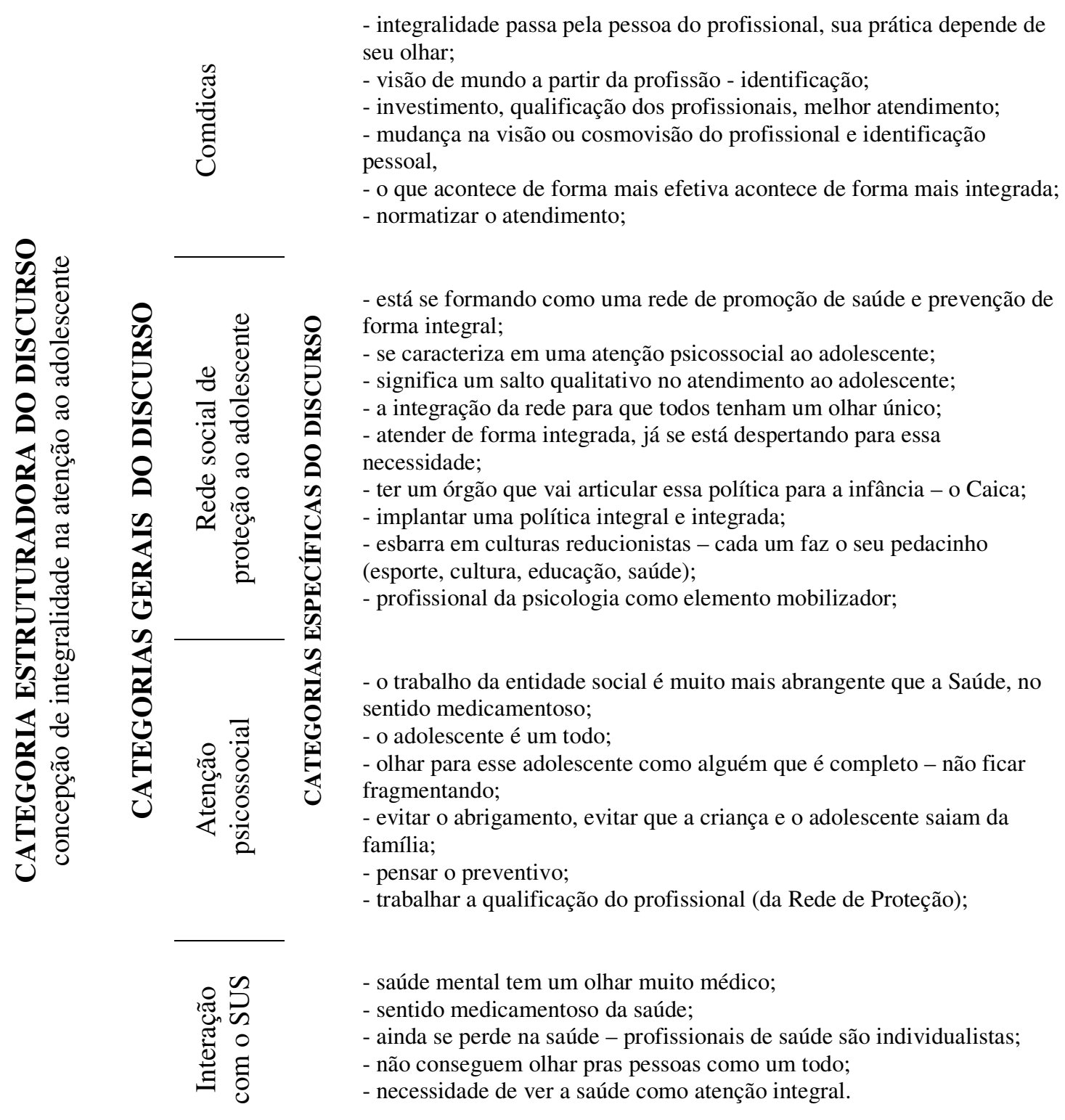




\section{2) Entrevista número dois realizada a treze de junho de dois mil e seis.}

Dados da entrevistada: MJ; 40 anos; divorciada; 01 filha; psicóloga especialista em neurolinguística e psicoterapia breve de grupos; residente na cidade de Mogi das Cruzes; coordenadora técnica de programas desenvolvidos pela entidade Comunidade Kolping do Jardim Revista.

Dados do trabalho desenvolvido pela entrevistada: a Comunidade Kolping do Jardim Revista atende adolescentes em cumprimento de medida sócio educativa em meio aberto. Oferece cursos de informática, cabeleireiro, acompanhamento psicossocial e sócio educativo, inclusive, reforço escolar e complementação alimentar. Localiza-se na periferia do município de Suzano, Jardim Revista; o bairro possui infra-estrutura de saneamento básico, transporte coletivo, vias públicas asfaltadas, escola pública municipal e estadual e uma UBS. Porém, observa-se uma situação de pobreza social, cultural, e, principalmente, econômica - muitos homens desempregados na rua. MJ coordena os projetos desenvolvidos na entidade e sua relação com as entidades governamentais como a Fundação Casa (antiga Febem) e o Comdicas, no qual desempenha a função de secretaria. 


\title{
SISTEMATIZAÇÃO DA NARRATIVA
}

\author{
FONTE: entrevista semi-estruturada
}

\section{SUJEITO DE PEQUISA:}

MJ; 40 anos; divorciada; 01 filha; psicóloga especialista em neurolinguística e psicoterapia breve de grupos; residente na cidade de Mogi das Cruzes; coordenadora técnica de programas desenvolvidos pela entidade Comunidade Kolping do Jardim Revista.

\footnotetext{
- desempenha uma função e responsabilidade social de transformação social;

- clareia a função da entidade social;

- interage com a sociedade civil e o poder público;

- fiscaliza as políticas públicas;

- poder público nas três esferas ainda não cumpriu o seu papel;

- se vive ainda muito do assistencialismo;

- se têm uma visão da entidade social como um equipamento de assistência social e não um equipamento de saúde - de atenção psicossocial;

- uma tentativa (a rede está se organizando);

- credenciamento e certificação das entidades - pequeno, médio e grande porte;

- estabelecimento institucional da rede;

○ - rede de proteção social com foco na atenção integral à saúde do adolescente;

- proteger o adolescente que vive maior vulnerabilidade pessoal e social; - espaço mais amplo de educação, saúde, lazer, preparação para o trabalho;

- necessidade de maior investimento e capacitação na busca de um olhar integral;

- ainda não se consegue ver o adolescente como um todo;

- o trabalho em rede em rede viabiliza o projeto político de integralidade de atenção integral nas entidades sociais;

- atendimento terapêutico - apoio, acolhimento, escuta, ser presença na vida dessas pessoas;

- queixa com relação à família que não o escuta, não há diálogo, não o deixa 'ser';

- ajuda-lo a procurar o seu referencial;

- drogadição: questão de saúde - esclarecimento, sensibilização intenção de informar, orientar, não condenar, encaminhamento médico (clínicas privadas);

- falta política pública: uma política de atuação com ações integradas para a saúde do adolescente;

- está se caminhando para esse olhar político

- há um olhar diferenciado, uma mudança histórica de cultura, não apenas em Suzano, é o contexto que está mudando;

- o médico vê a entidade social como um lugar para dar comida, conter violência;

- o tempo de espera para uma consulta é muito longo;

- um atendimento muito biológico e pouco psicossocial;

- o médico não tem preocupação com a integralidade;

- os profissionais da saúde não compreendem as entidades sociais como equipamentos de saúde, de promoção da saúde;

- necessidade de políticas integradas no município;

- integrar os serviços para dar resposta integral à demanda adolescente.
} 


\section{3) Entrevista número três realizada a dezoito de julho de dois mil e seis.}

Dados da entrevistada: LN; 40 anos; formada em Letras com curso de especialização em gestão de projetos empresariais; casada; dois filhos; residente no município de Suzano.

Dados do trabalho desenvolvido pela entrevistada: LN é gestora e coordenadora da Fundação Orsa - Unidade Formação Suzano, que desenvolve ações sócio educativas com crianças e adolescentes no distrito de Palmeiras, município de Suzano. Uma região que conta com população estimada em 25.000 habitantes distribuídos em 89 bairros isolados. Pessoas vivendo em condições precárias de alimentação, habitabilidade, segurança, saneamento básico e saúde. Apesar de existirem várias indústrias na região, sua população não tem acesso às vagas de emprego devido a baixa escolaridade e falta de qualificação profissional. Na maior parte dos bairros a única referência de política pública é a escola. Caracteriza-se por uma região agrícola em que uma considerável parcela da população ativa trabalha no plantio de hortas, como caseiros e serviços domésticos em chácaras de lazer. Uma outra parcela trabalha no comércio e indústria fora do município. LN atua como conselheira no Comdicas presidindo a comissão de documentos e convênios - que avalia a documentação das entidades sociais para o cadastro em convênio com a prefeitura. 


\title{
SISTEMATIZAÇÃO DA NARRATIVA
}

\author{
FONTE: entrevista semi-estruturada
}

\section{SUJEITO DE PEQUISA:}

LN; 40 anos; formada em Letras especializada em gestão de projetos empresariais; gestora e coordenadora da Fundação Orsa; preside a comissão de documentos e convênios no Comdicas.

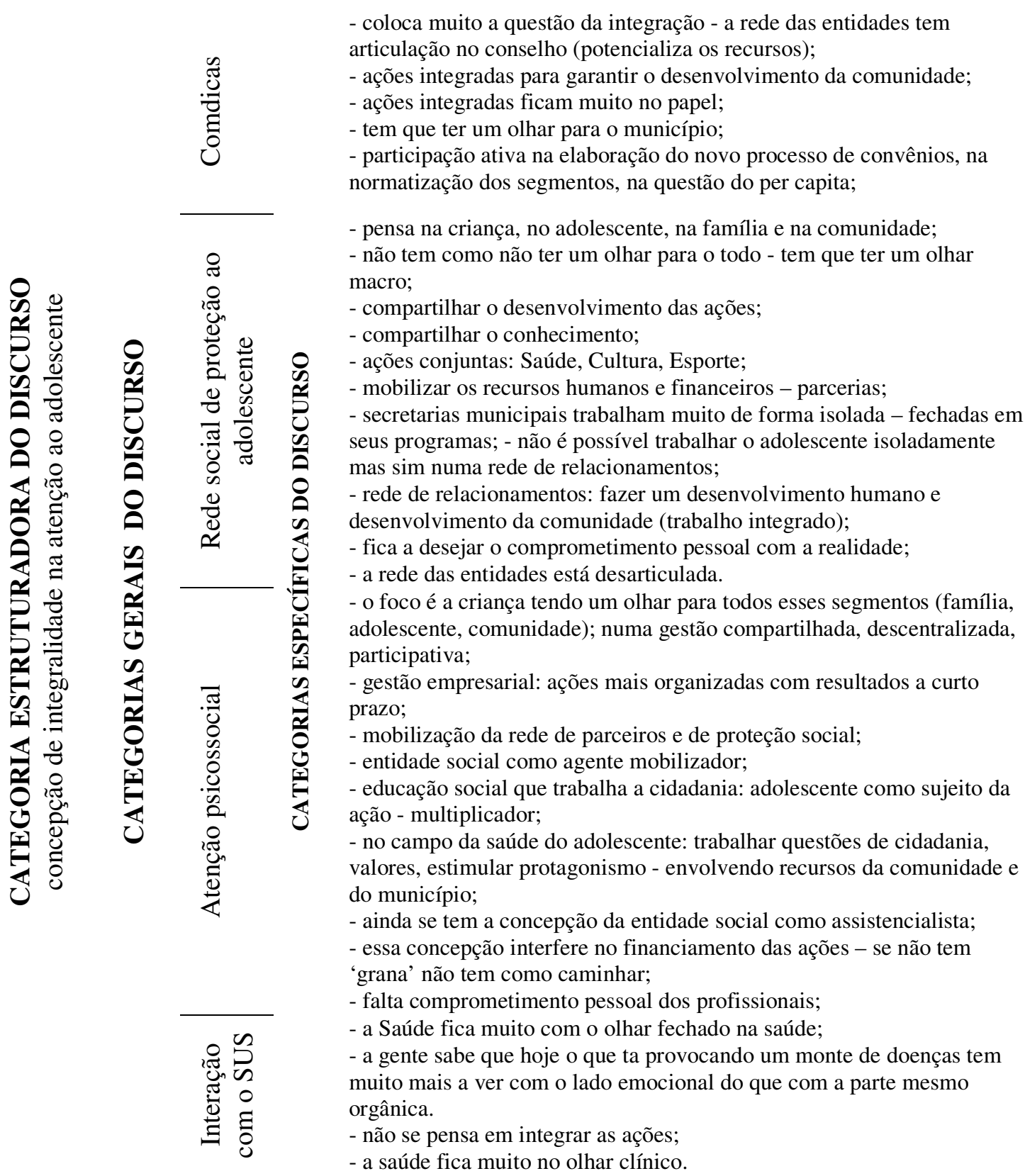




\section{4) Entrevista número quatro realizada a dois de agosto de dois mil e seis.}

Dados do entrevistado: M; 37 anos; divorciado; uma filha de dezesseis anos; Técnico em Química; Cursando Pedagogia; residente no município de Suzano.

Dados do trabalho desenvolvido pelo entrevistado: M, estudante de Pedagogia, além de presidente do Comdicas é diretor de Políticas Sociais na Secretaria Municipal de Promoção da Cidadania e Inclusão Social. Militante atuante nos movimentos sociais de defesa dos direitos da criança e do adolescente foi educador social em entidades sócioeducativas de atenção à criança e ao adolescente - como a Comunidade Kolping. Membro eleito no primeiro Conselho Tutelar de Suzano responsável em organizar o regimento e a implantação desse órgão na cidade. Presidiu o Fórum Municipal de Entidades Sociais que agregava lideranças de diversas entidades para reivindicar junto ao governo melhorias na política social.. Hoje, como diretor de políticas sociais, constituiu sua equipe com lideranças do antigo Fórum das Entidades Sociais, segundo sua fala procura colocar em prática as questões que outrora reivindicava. 


\section{SISTEMATIZAÇÃO DA NARRATIVA \\ FONTE: entrevista semi-estruturada \\ SUJEITO DE PEQUISA:}

M; 37 anos; Técnico em Química; cursando Pedagogia; diretor de Políticas Sociais na Secretaria Municipal de Promoção da Cidadania e Inclusão Social; preside o Comdicas.

\footnotetext{
- trabalhando no princípio da territorialização ações entre governo, sociedade civil e comunidade;

- certificação: ver onde estão e qual seu objetivo - habilitação a um serviço (não um controle da ação da entidade, mas, a qualificação da rede);

- com a certificação das entidades vai se dando uma nova dimensão ao trabalho social - uma visão mais integrada;

- entidades sociais como uma extensão da política de governo - parceiras, trabalho conjunto sem sobrepor (a entidade como parte da rede de proteção);

- que a entidade tenha foco no seu local de origem e desenvolva a cultura de trabalhar integrada à rede pública e com outras entidades;

- necessidade de ter o perfil e de ouvir a opinião da criança/adolescente para evitar o risco de falar na criança sem falar dela - dar voz ao usuário;

- é um mútuo aprendizado: entre técnicos, entidades e comunidade - mudanças de paradigmas;

- descentralização dos serviços nas quatro regiões da cidade e em micro regiões; - criação da Coordenadoria da Criança e do Adolescente - órgão de governo que garanta e articule as políticas para a integralidade dos serviços da rede; -grande desafio: as secretarias que trabalham com o mesmo público garantirem trabalho integrado;

- historicamente cada secretaria assume a obrigação de fazer bem o seu trabalho - a cultura do trabalho conjunto esta sendo construída (os serviços precisam se integrar de forma que possam se complementar e ser mais eficiente);

- precisa estar claro na cabeça não apenas dos gestores das políticas, mas, dos servidores que precisam sentir a necessidade de sua secretaria fazer uma interface com outra secretaria;

- um exemplo de integralidade é o Bolsa Família que traz esses três pilares: a educação, a saúde e a política social;

- atender crianças e adolescentes que vivem maior vulnerabilidade;

- trabalhar em três pilares: atender a criança e o adolescente, a família e articular com a rede pública (para que tanto a entidade quanto o servidor olhem para o entorno e se comprometam com aquela região);

- necessidade de capacitar os servidores e entidades sociais para o olhar da integralidade;

- desafio: famílias são resistentes em cumprir sua parte;

- ter centralidade no usuário;

- é preciso que haja uma consciência do servidor público - há um problema de concepção dos trabalhadores nesse serviço (um problema de apropriação);

- a cultura de integralidade dos serviços é muito recente;

- está concebido por lei: é preciso sempre observar, revisar enquanto integração dos serviços;

- o Eca é o maior provocador dessa relação: propõe ao trabalho um conjunto de ações voltadas à saúde , à educação, ao esporte/lazer, cultura;

- a integralidade dos serviços tem um ponto de vista econômico;

- é preciso mais investimento, mas, antes é preciso avaliar como são gastos os recursos atuais;

- necessidade de promover saúde;

- desenvolver e ampliar essa visão social de saúde;

- ainda se tem a mentalidade de que a entidade faz o serviço social, o posto dá o remédio...
} 
5) Entrevista número cinco realizada a quatro de agosto de dois mil e seis.

Dados do entrevistado: HS; 42 anos, cirurgião dentista; casado; três filhos; residente em Suzano.

Dados do trabalho desenvolvido pelo entrevistado: coordenador da Saúde Bucal na Secretaria Municipal da Saúde de Suzano; membro da Comissão de Fiscalização do Comdicas. É o representante da Secretaria Municipal da Saúde - referência do Conselho com o SUS. 


\title{
SISTEMATIZAÇÃO DA NARRATIVA
}

\author{
FONTE: entrevista semi-estruturada
}

\section{SUJEITO DE PEQUISA:}

HS; 42 anos, cirurgião dentista; membro da Comissão de Fiscalização; coordenador da Saúde Bucal na Secretaria Municipal da Saúde de Suzano é o representante do SUS no Comdicas

\footnotetext{
- acompanhamento burocrático das entidades - fiscalização, suporte técnico, para darem atendimento às crianças e aos adolescentes em todos os aspectos;

- informações de como se pode elaborar um plano mais integrado;

- para ela (entidade) ser certificada, para ser registrada, ajudando-a a se organizar;

- replanejar ou providenciar uma ação com relação àquela entidade;

- a gente ta buscando suprir tudo isso - investimentos em recursos humanos;

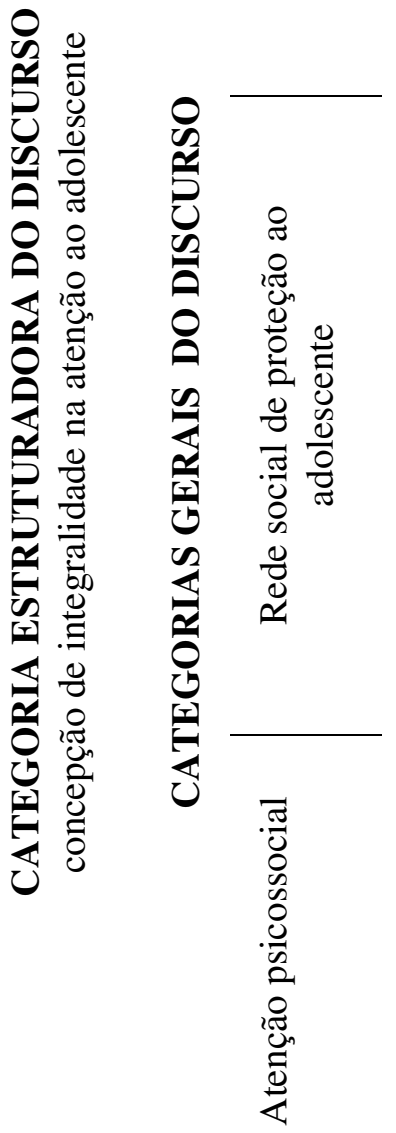

- Comdicas com ações de uma política integrada;

- é cada um com sua força de vontade em querer fazer parte da ação;

$\approx \quad$ - cada membro vestir a camisa porque dá pra fazer perfeito;

- vai depender de como eu enxergo - o projeto existe, é uma integralidade que depende de cada um;

- a integralidade acontece mas depende de cada um de nós;

- todos os serviços deveriam estar articulados naquilo que o poder público tem que fazer na sua integralidade;

- a gente ta tentando articular uma rede com as instâncias municipais públicas;

- qualquer serviço público tem que pensar no indivíduo como um todo;

- é um trabalho árduo - depende da vontade de todos os parceiros (de cada membro também);

- rede organizada pra oferecer informações em saúde - preparar, capacitar RHs;

- o que atrapalha é a individualidade de cada um, a ambição do poder, o egoísmo, vaidade, ganância;

- existe um pouco de sonho aí mas existe um pouco de realidade.

- entidades sociais como equipamentos de promoção e prevenção em saúde;

- precisa ter RHs com esta capacitação - formação de grupos de pessoas que são capacitadas para fazer esta promoção e esta prevenção;

- precisa investimentos em recursos humanos;

- o trabalho de prevenção é muito mais efetivo se você realizar no local onde o adolescente está,

- ao trabalhar com indivíduos você tem que pensar na integralidade desses indivíduos;

- integralidade na dependência da cosmovisão do gestor da entidade e dos processos;
} 
- o membro da Saúde faz encaminhamentos, planejamento e ações em saúde;

- trabalho preventivo e curativo;

- muitas vezes uma criança, um adolescente, não precisa de um tratamento propriamente curativo, no sentido orgânico, mas psicológico;

- a parte psíquica é a parte mais difícil;

- a saúde já faz um atendimento ao adolescente na Rede de Saúde - o atendimento é universal;

- temos que atender toda a população independente da faixa etária;

- o adolescente dificilmente procura a unidade de saúde; e, quando o faz, geralmente procura para um atendimento curativo,

- equipe gestora do trabalho de DST/AIDS - capacitação de adolescentes para que eles possam ver a prevenção nas escolas e nos espaços sociais;

- saúde não é só cuidar do corpo físico;

- toda sociedade quando ta promovendo a vida de alguém ta promovendo saúde;

- na verdade tudo sobra pro SUS uma das únicas políticas públicas que se propõe a atender toda a população;

- saúde é muito mais que oferecer serviços de saúde;

- não tem como a Saúde assumir tudo o que tem de ser oferecido para se ter saúde - é impossível;

- para falar em saúde tem que ter uma condição social inteira senão fica só no biológico;

- a Saúde precisa de articulação - políticas integral e integrada;

- tem que integrar para oferecer tudo. 


\section{6) Entrevista número seis realizada a quinze de setembro de dois mil e seis.}

Dados do entrevistado: NT; 52 anos; casado; três filhos; microempresário; formado em Direito; residente no município de Suzano.

Dados do trabalho desenvolvido pelo entrevistado: A Guarda Mirim de Suzano é uma entidade de cunho sócio educativo e acompanhamento psicossocial. Desenvolve junto a adolescentes, de ambos os sexos, formação pré profissionalizante e ingresso dos adolescentes no mundo do trabalho por meio de parcerias com empresas locais. Localiza-se na região central do município de Suzano, Jardim Colorado; o bairro possui infraestrutura de saneamento básico, transporte coletivo, vias públicas asfaltadas, escola pública municipal e estadual e uma UBS. Porém, observa-se uma situação de pobreza social, cultural e, principalmente econômica. NT é presidente na diretoria executiva da Guarda Mirim de Suzano, supervisiona os projetos desenvolvidos na entidade e sua relação com os órgãos governamentais como o Comdicas e as parcerias com empresas locais. 


\title{
SISTEMATIZAÇÃO DAS NARRATIVAS
}

\author{
FONTE: entrevista semi-estruturada
}

\section{SUJEITO DE PEQUISA:}

NT; 52 anos; microempresário; formado em Direito; preside a diretoria executiva da Guarda Mirim de Suzano.

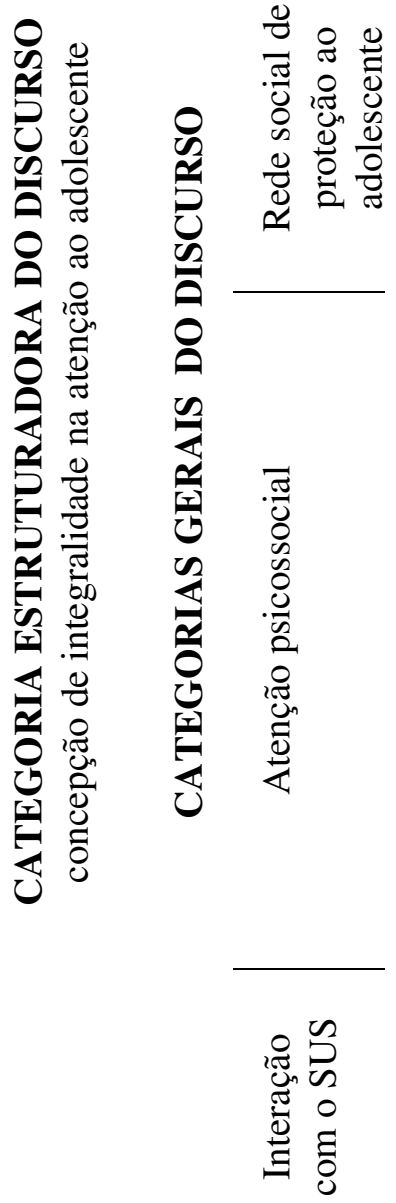

- visita às entidades: renovação de registro, formulação de convênio; - cada entidade tem sua personalidade é preciso preservar sua história;

- formação de multiplicadores, lideranças;

- se dá com a atuação no Comdicas;

- formação pré-profissional - técnicas comerciais, datilografia, informática, educação moral e cívica (respeito, saber lidar com concorrentes, respeito à família, menos agressão, menos violência);

- formação educacional para o trabalho com objetividade - Lei do Aprendiz; desenvolvimento de programas com profissionais qualificados; - noções de meio ambiente e higiene pessoal;

- atividades físicas, esportivas e lúdicas/recreação (inclusive como instrução);

- formação da cidadania - senso crítico, questão política, cidadãos conscientes e esclarecidos - para participar da política;

- atividade com psicóloga - tratamento da auto-estima, observação e intervenção constante quanto a timidez;

- assistência social - apoio sócio familiar;

- projeto empresa virtual;

- todo o suporte para o jovem desenvolver seu potencial - só precisa da boa vontade e do querer;

- dificuldade, o mercado não está absorvendo os jovens que se formam, não há vagas;

- avaliação médica;

- atenção integrada ao SUS se dá a partir de encaminhamentos para a rede assistencial quando se faz necessário;

- informação e cuidados em saúde - postura física, meio ambiente, orientação alimentar, drogas;

- acompanhamento psicológico. 


\section{RESULTADOS E DISCUSSÃO}

Compreender a noção de integralidade emergente, no discurso desses agentes sociais, significou mergulhar numa polifonia na qual apareceu a necessidade da busca. Já desde o primeiro instante os informantes exprimiram a intencionalidade de apreender “como um todo" o fenômeno da adolescência, ou seja, revelaram uma busca de compreensão a partir da integralidade. Porém, o que mais apareceu no imediato da busca não foi a noção da integralidade e sim a realidade do cotidiano. Constituída deste ou daquele modo revelou as noções estabelecidas a partir de uma prática socialmente construída.

Investigar a noção de integralidade presente neste mundo de cotidianidade, vê-la e ouvi-la, senti-la e percebê-la, encontrar seus vestígios em cada palavra pronunciada, nos conduziram a uma mesma busca. Pesquisador e sujeitos de pesquisa se tornaram, de alguma forma, parceiros. Nessa procura ela se mostrou em perspectivas ou conhecimentos tão diferentes que, na insistência da objetividade, revelou-se na convergência dos discursos como um enunciado. Antes, porém, de sofrer as determinações da objetividade, de constituir-se nesta ou naquela conceituação, se mostrou como referência. Como pensamento que posiciona o sujeito no seu mundo.

Há nos seis discursos o fascínio pelo conhecimento da integralidade. E, embora, se diferenciem, e, se constituam em diversidade, sempre se referem. Sempre falam. Neles há sempre uma intencionalidade de constituir um discurso integral sobre a integralidade. 
Se a integralidade no seu mostrar-se, estimula a pensá-la, há uma referência ao seu ser. Que se apresenta como uma expressão guia: integralidade como proposição a qualquer tipo de reducionismo. Revelou-se como expressão máxima da ação dos agentes sociais. Isto significa que a integralidade, nesse mostrar-se, se apresenta como desafio não apenas às práticas em saúde tradicionalmente construídas. Mas, como inquietação para o já inquieto campo da saúde pública. Precisamente por se prestar ao conhecimento, por ajudar o pensamento em saúde, a voltar o olhar para si mesmo. Neste sentido essa expressão guia apresentou-se como idéia referência.

E o interessante é que, neste trabalho, o objeto de estudo estando na intersecção entre o campo da saúde pública e o campo da promoção social, desvelou o conhecimento da integralidade em todas as suas modalidades e se apresentou, num primeiro momento, como desconhecida. O admirável é que ela esteve presente: o informante a vive, a vê, a ouve, suspeita e descobre ela está na cotidianidade. E quando, no cessar dos afazeres, se dedicou a pensá-la. Percebeu que a cotidianidade escondia o ser de sua busca. Por isso o cotidiano nos inquietou e nos atraiu. Quanto mais o pensamento se entregou à inquietação do cotidiano, tanto mais interpretou a polissêmica noção de integralidade.

\footnotetext{
"O desconhecido não é aquilo a respeito do qual não sabemos absolutamente nada, mas é aquilo que, no que conhecemos, se impõe a nós como elemento de inquietação (Heidegger, 1983: 217)
}

Essa aproximação foi possível por tratar-se de um entendimento prévio. Prévio porque iniciou e estruturou a questão da integralidade. Não foi um entendimento subseqüente a questão, mas anterior e apenas indicado por quem já estava na fadiga da questão. Foi uma pré compreensão da procura. A fadiga sinalizou a compreensão 
autêntica sobre aquilo que se revelava. A rotina, o trabalho, a vida comprimida no tempo, nos afazeres, nos ajudou a ancorar a procura e encontrar na fala do agente social o que ele mais conhece.

Ao nos propormos à compreensão de integralidade, num sentido determinado, nos demos conta de que, por meio de diferentes discursos, perpassou um sentido indeterminado. E que foi pela indeterminação dos discursos, por mais contrastante que se apresentavam, e, mesmo, em virtude de sua indeterminação, é que apareceu a possibilidade de determinar. Então, à primeira vista pareciam palavras vazias, desconexas. Mas, ao demorarmos na leitura das entrevistas surgiu uma riqueza de sentidos que se mantiveram ocultos. Por conseguinte, o presente nomeou a integralidade por desdobramentos que perfizeram o expressar e o aparecimento. O que é, apareceu. Indicando que a investigação desvelou, em tudo, o que apareceu. Sem afastar-se da compreensão de integralidade como um paradigma, como uma idéia referência às ações e práticas no campo da saúde. 


\title{
1. A compreensão de integralidade como um paradigma - uma idéia referência
}

\begin{abstract}
“ Mas ser-no-mundo não quer dizer que o homem se acha no meio da natureza, ao lado de árvores, animais e outros homens ... É uma estrutura de realização... O homem está sempre superando os limites entre o dentro e o fora."
\end{abstract}

(Heidegger, 1988: 20)

Mergulhando, agora no discurso desses atores sociais, em sua linguagem, a partir dessa compreensão, temos a oportunidade de caracterizar o lugar da integralidade nessa rede de proteção social ao adolescente como um paradigma, como uma idéia referência às ações e práticas no campo da saúde.

No mundo habitado pelos agentes sociais entrevistados a integralidade é entendida num campo de relações. E o agente social aparece como o constituidor desse campo de relações porque seu olhar se estende, interage e se relaciona com tudo que o cerca. E isso o torna no seu agir ser-no-seu-mundo e com-o-seu-mundo. Suas práticas sociais são extensões de sua cosmovisão e o submetem a determinada ordem, a determinada circunstância.

Por acontecer nos embaraços e nas vicissitudes desse mundo, por não poder realizar-se senão no mundo e com o mundo, sua prática é por ele circunstanciada. Ele, porém, se compõe como interação também circunstancial. Ao conhecê-lo e acessar suas concepções necessitamos olhar o seu ambiente, analisar o seu mundo e compreender sua circunstância. 
O que o possibilitou a constituir-se como ser-no-seu-mundo e com-o-seu-mundo

foi a necessidade de estimar/prever a disponibilidade dos recursos ao seu alcance. Essa necessidade estimadora o instalou a si mesmo como condição que instrumentaliza tornando cada ação uma coisa útil. Essa utilidade consiste em fazer aparecer o traço fundamental que, em seu discurso, emergiu como o diferencial na atenção integral que comporta os programas e a política pública na qual está inserido, qual seja, a categoria existencial.

Em sua concepção a atenção à saúde, no contexto do SUS, enquanto equipamentos, profissionais e práticas situam-se na preocupação médica com a vida. $\mathrm{Na}$ preocupação com a manutenção da vida do ponto de vista biológico. Em manter vivo o organismo doente sem, no entanto, voltar o olhar para a qualidade de vida, para a existência da pessoa doente. Mostra-se um olhar reducionista para a doença e não para a pessoa que adoece. A política pública em saúde e seus profissionais aparecem voltados para ações no campo da medicina, do ambulatório e da clínica..

\footnotetext{
“... ainda se perde na saúde, profissionais de saúde são individualistas; não conseguem olhar pras pessoas como um todo; a saúde mental tem um olhar muito médico; sentido medicamentoso da saúde; (MC)”; “... o médico vê a entidade social como um lugar para dar comida, conter violência; um atendimento muito biológico e pouco psicossocial; o médico não tem preocupação com a integralidade; os profissionais da saúde não compreendem as entidades sociais como equipamentos de saúde, de promoção da saúde (MJ)”; “... a Saúde fica muito com o olhar fechado na saúde; a gente sabe que hoje o que ta provocando um monte de doenças tem muito mais a ver com o lado emocional do que com a parte mesmo orgânica; a saúde fica muito no olhar clínico (LN)”; “... é preciso que haja uma consciência do servidor público - há um problema de concepção dos trabalhadores nesse serviço (um problema de apropriação); ainda se tem a mentalidade de que a entidade faz o serviço social, o posto dá o remédio...; necessidade de promover saúde; desenvolver e ampliar essa visão social de saúde $(M)$ ”.
}

$\mathrm{Na}$ interação da Rede de Proteção Social ao Adolescente com o SUS os discursos apresentam uma "necessidade de ver a saúde como atenção integral (MC)" $\mathrm{e}$ 
de “integrar os serviços para dar resposta integral à demanda adolescente (MJ)" $\mathrm{e}$ assim, emerge a "necessidade de políticas integradas no município (LN)". Contudo acredita-se que "a cultura de integralidade dos serviços é muito recente (M)" apesar de “estar concebido por lei: é preciso sempre observar, revisar enquanto integração dos serviços (M)” e sinalizam que “o Eca é o maior provocador dessa relação: propõe ao trabalho um conjunto de ações voltadas à saúde, à educação, ao esporte/lazer, cultura $(M)$ ”. Nesse olhar do agente social as ações em saúde se reduzem a ações no âmbito restrito ao Sistema Único de Saúde e sinalizam o importante papel do profissional em saúde para promover a integração dos serviços, para promover a integralidade.

Há no discurso do conselheiro HS, que no conselho representa o SUS, uma intencionalidade, uma tentativa, de preocupar-se com a existência dos usuários nos serviços de saúde, porém, o que aparece e se firma é a preocupação com a vida em sua dimensão biológica e orgânica quando afirma que, "a saúde já faz um atendimento ao adolescente na Rede de Saúde - o atendimento é universal (HS)”; e esse atendimento se dá com um "trabalho preventivo e curativo"; "o membro da Saúde faz encaminhamentos, planejamento e ações em saúde”; observa-se que "muitas vezes uma criança, um adolescente, não precisa de um tratamento propriamente curativo, no sentido orgânico, mas psicológico”; porém “a parte psíquica é a parte mais difícil”. E procura justificar-se que "enquanto sistema de saúde na verdade tudo sobra pro SUS uma das únicas políticas públicas que se propõe a atender toda a população”; "temos que atender toda a população independente da faixa etária"; apesar do "adolescente dificilmente procurar a unidade de saúde"; a "equipe gestora do trabalho de DST/AIDS oferece capacitação de adolescentes para que eles possam ver a prevenção nas escolas e nos espaços sociais"; acrescenta ainda que "saúde não é só cuidar do 
corpo físico"; e, mais "saúde é muito mais que oferecer serviços de saúde”; sinaliza a necessidade de integralidade dos serviços "não tem como a Saúde assumir tudo o que tem de ser oferecido para se ter saúde - é impossível”; reflete sobre uma noção integral de saúde "toda sociedade quando ta promovendo a vida de alguém ta promovendo saúde”; "para falar em saúde tem que ter uma condição social inteira senão fica só no biológico"; e, enquanto política pública, "a Saúde precisa de articulação - políticas integrais e integradas"; e conclui "tem que integrar para oferecer tudo".

Se o olhar do agente social sobre o SUS percebe uma preocupação com a vida dos usuários do ponto de vista biológico. Por outro lado, observa que nas entidades sociais se apresenta uma preocupação diferenciada. Uma preocupação com a existência do usuário adolescente numa perspectiva de atenção psicossocial, “... o adolescente é um todo; o trabalho da entidade social é muito mais abrangente que a Saúde; olhar para esse adolescente como alguém que é completo; não ficar fragmentando; pensar o preventivo $(M C)$ ”. Essa posição implica em evitar compreensões reducionistas tanto do ponto de vista psicológico, quanto médico ou social o “ atendimento terapêutico: apoio, acolhimento, escuta ser presença na vida dessas pessoas; ajudá-los a procurar o seu referencial; (olhar a) drogadição como questão de saúde, esclarecimento, sensibilização intenção de informar, orientar, não condenar, encaminhamento médico (MJ)”; “... o foco é a criança, tendo um olhar para todos esses segmentos - família, adolescente, comunidade; no campo da saúde do adolescente: trabalhar questões de cidadania, valores, estimular protagonismo - envolvendo recursos da comunidade e do município $(L N)$ ”. O desafio a ser superado é imenso “... ao trabalhar com indivíduos você tem que pensar na integralidade desses indivíduos; entidades sociais como equipamentos de promoção e prevenção em saúde $(H S)$ ”. Vida e existência se 
manifestam como dimensões circunstanciais nas quais as pessoas estão inseridas. E um olhar integral sobre essas dimensões é imprescindível quando se trata de uma atenção psicossocial.

Os conselheiros, no Comdicas, e, na Rede de Proteção Social como um todo, têm-se preocupado com o conhecimento e a compreensão dessas dimensões em sua ação junto à demanda adolescente “... atender crianças e adolescentes que vivem maior vulnerabilidade; - trabalhar em três pilares: atender a criança e o adolescente, a família e articular com a rede pública (M)”; "política pública: uma política de atuação com ações integradas para a saúde do adolescente (MC)”; “...numa gestão compartilhada, descentralizada, participativa educação social que trabalha a cidadania: adolescente como sujeito da ação - multiplicador (LN)”. Profundas reflexões e estudos foram feitos ao longo do ano em que acompanhamos o trabalho desenvolvido "há um olhar diferenciado, uma mudança histórica de cultura, não apenas em Suzano, é o contexto que está mudando $(M J)$ ”. Destes foram emergindo uma multiplicidade de abordagens, de olhares e práticas em integralidade falas como "evitar o abrigamento, evitar que a criança e o adolescente saiam da família; trabalhar a qualificação do profissional (da Rede de Proteção) (MC)”; com um olhar diferenciado para uma "gestão empresarial: ações mais organizadas com resultados em curto prazo; mobilização da rede de parceiros e de proteção social (LN)"; conformam uma abordagem em que aparece a "entidade social como agente mobilizador (LN)", "está se caminhando para esse olhar político $(M J) ”$.

Uma das razões para a multiplicidade de abordagens de integralidade na intersecção entre os campos da saúde e da promoção social consiste em que ao questionar-se sobre a integralidade das ações, das práticas, das concepções e das 
políticas desvela-se o ser que questiona "integralidade na dependência da cosmovisão do gestor da entidade e dos processos $(H S)$ ”. O fato de o humano desvelar-se nessas discussões revela o próprio existir, "o que atrapalha é a individualidade de cada um, a ambição do poder, o egoísmo, vaidade, ganância $(H S)$ ”. E de ser, este, muito amplo e complexo "é um trabalho árduo - depende da vontade de todos os parceiros (de cada membro também) (HS)". Nesse desvelamento percebe-se que o fenômeno da integralidade é vivido, imediatamente, pelas pessoas que o pretendem utilizar, mas, para manter determinada atitude elas procuram estudá-lo, aprofundá-lo, compreendê-lo e, portanto, conhecê-lo por meio das próprias instituições que compreendem a rede, "necessidade de capacitar os servidores e entidades sociais para o olhar da integralidade; ter centralidade no usuário; para que tanto a entidade quanto o servidor olhem para o entorno e se comprometam com aquela região $(M)$ ”; "pensar na criança, no adolescente, na família e na comunidade; não tem como não ter um olhar para o todo - tem que ter um olhar macro; compartilhar o desenvolvimento das ações; compartilhar o conhecimento $(L N) ”$.

Ocorre que instituições e rede são compostas por pessoas. São entidades que existem na imanência do vivido. E não apenas na transcendência categorial que comporta as reflexões do Conselho "falta comprometimento pessoal dos profissionais $(L N)$ ”; “desafio: famílias são resistentes em cumprir sua parte (M)”. Os conselheiros, ao estudarem a rede, passam a ser os sujeitos de suas investigações "esbarram em culturas reducionistas - cada um faz o seu pedacinho (secretarias do esporte, cultura, educação, saúde) (MC)”. Porém, o existir desses sujeitos não apresenta apenas aspectos passíveis de observação em suas manifestações exteriores. Mas contém outros que ficam ocultos aos mais competentes e atentos observadores "existe um pouco de sonho 
aí, mas existe um pouco de realidade $(H S)$ ”. Por ocorrerem no íntimo das pessoas "precisa estar claro na cabeça não apenas dos gestores das políticas, mas, dos servidores que precisam sentir a necessidade de sua secretaria fazer uma interface com outra secretaria (HS)”. Acontece que estas não são transparentes e geralmente não revelam suas intimidades "é cada um com sua força de vontade em querer fazer parte da ação; cada membro vestir a camisa porque dá pra fazer perfeito; vai depender de como eu enxergo; o projeto existe, é uma integralidade que depende de cada um; a integralidade acontece, mas depende de cada um de nós (HS)”. Além disso, passam por fenômenos que nem sempre chegam a perceber, por ocorrem num nível muito profundo, muitas vezes inconsciente.

“... precisa ter RHs com esta capacitação - formação de grupos de pessoas que são capacitadas para fazer esta promoção e esta prevenção; precisa investimentos em recursos humanos; o trabalho de prevenção é muito mais efetivo se você realizar no local onde o adolescente está (HS)”. “... historicamente cada secretaria assume a obrigação de fazer bem o seu trabalho - a cultura do trabalho conjunto esta sendo construída (os serviços precisam se integrar de forma que possam se complementar e ser mais eficiente) (M)”.

Acresce, ainda, que o existir cotidiano está repleto de aspectos contrastantes como, por exemplo, quando na dedicação do cuidado com o bem-estar do outro, ao mesmo tempo, a pessoa se empenha em sua própria realização pessoal "fica a desejar o comprometimento pessoal com a realidade $(L N)$ ”. No cuidado com pessoas, seja na saúde ou qualquer outra área, o profissional se confronta consigo mesmo, com suas concepções e valores, não consegue evitar as angústias e aflições "todos os serviços deveriam estar articulados naquilo que o poder público tem que fazer na sua integralidade; a gente ta tentando articular uma rede com as instâncias municipais públicas; qualquer serviço público tem que pensar no indivíduo como um todo; rede organizada pra oferecer informações em saúde - preparar, capacitar RHs (HS)"; o 
conselheiro percebe o "grande desafio: as secretarias que trabalham com o mesmo público garantirem trabalho integrado $(M)$ ”; “ secretarias municipais trabalham muito de forma isolada - fechadas em seus programas; não é possível trabalhar o adolescente isoladamente mas sim numa rede de relacionamentos (LN)"; e vislumbra a "necessidade de maior investimento e capacitação na busca de um olhar integral; ainda não se consegue ver o adolescente como um todo (MJ)”; e na realidade “esbarram em culturas reducionistas - cada um faz o seu pedacinho (esporte, cultura, educação, saúde) (MC)”.

Todas essas complexidades e contrastes no existir cotidiano são vivenciados como uma totalidade que integra todas as ações, pois "não tem como não ter um olhar para o todo - tem que ter um olhar macro; compartilhar o desenvolvimento das ações; compartilhar o conhecimento; ações conjuntas: Saúde, Cultura, Esporte (LN)”. De modo vivencialmente global se "pensa na criança, no adolescente, na família e na comunidade", para “mobilizar os recursos humanos e financeiros - parcerias", numa "rede de relacionamentos: fazer um desenvolvimento humano e desenvolvimento da comunidade (trabalho integrado) (LN)”.

Esta situação viabilizou o "credenciamento e certificação das entidades pequeno, médio e grande porte", com o "estabelecimento institucional da rede", e uma "rede de proteção social com foco na atenção integral à saúde da criança e do adolescente (MJ)"; e ao poder público propor ao Conselho a "descentralização dos serviços nas quatro regiões da cidade e em micro regiões", com a "criação da Coordenadoria da Criança e do Adolescente - órgão de governo que garanta e articule as políticas para a integralidade dos serviços da rede (M)”. Acredita-se que "o 
trabalho em rede viabiliza o projeto político de integralidade da atenção (M)”; principalmente o trabalho "integral nas entidades em proteger o adolescente que vive maior vulnerabilidade pessoal e social", e a rede de proteção social como "espaço mais amplo de educação, saúde, lazer, preparação para o trabalho (MJ)”. Assim, a rede “está se formando como uma rede de promoção de saúde e prevenção de forma integral", e, "se caracteriza em uma atenção psicossocial ao adolescente", isto "significa um salto qualitativo no atendimento ao adolescente; a integração da rede para que todos tenham um olhar único", e "já se está despertando para essa necessidade de atender de forma integrada”, com isso o conselho possibilita e viabiliza “implantar uma política integral e integrada $(M C) ”$.

O Comdicas apresentou-se, sobremaneira, com o intuito de estabelecer nessa Rede um conjunto de proposições conectadas e implicadas no contexto social no qual se insere para desenvolver um saber decorrente das aflições, dúvidas e inquietações dos atores sociais que a compõem. Não podendo esse contexto ser decomposto. O agente social, a entidade social, a política pública, as ações de governo, a sociedade civil, entre outras, constituem uma estrutura primordial que pode, e foi, visualizada e descrita em seus vários momentos constitutivos pelo Conselho, mas, sempre mantendo a sua unidade. Desse modo, o conjunto de relações significativas dentro do qual o conselho existe e mantém-se, embora seja vivenciado como uma totalidade, apresenta-se paradoxalmente sob aspectos simultâneos e distintos aos seus membros. Segundo os quais o Comdicas:

“... desempenha uma função e responsabilidade social de transformação social; clareia a função da entidade social; interage com a sociedade civil e o poder público; fiscaliza as políticas públicas (MJ)"; “.... coloca muito a questão da integração - a rede das entidades tem articulação no conselho (potencializa os recursos); ações integradas para garantir o desenvolvimento 
da comunidade; tem que ter um olhar para o município; participação ativa na elaboração do novo processo de convênios, na normatização dos segmentos, na questão do per capita (LN)”; “... acompanhamento burocrático das entidades - fiscalização, suporte técnico, para darem atendimento às crianças e aos adolescentes em todos os aspectos; informações de como se pode elaborar um plano mais integrado; para ela (entidade) ser certificada, para ser registrada,ajudando ela a se organizar (HS)".

Há um movimento dialético nas diversas ações desempenhadas pelo conselho que procura adaptar-se aos elementos que o constituem "trabalhando no princípio da territorialização ações entre governo, sociedade civil $e$ comunidade (M)”. Esteve sempre tentando e, de certo modo, chegou a conseguir exercer alguma intervenção e acompanhamento da rede a partir de sua "certificação: ver onde estão e qual seu objetivo - habilitação a um serviço (não um controle da ação da entidade, mas, a qualificação da rede); com a certificação das entidades vai se dando uma nova dimensão ao trabalho social - uma visão mais integrada $(M)$ ”. E propor a compreensão de que a promoção social deriva de uma cosmovisão integral não apenas das ações, dos serviços, das políticas ou das posturas pessoais dos atores sociais. Mas, na manutenção das potencialidades que lhes são próprias em virtude de compreenderem as circunstâncias que vivenciam tendo consciência de si e do mundo, portanto, de sua existência. E como a existência consiste em ser-no-mundo o agente social atualiza tais potencialidades sendo-no-mundo. E assim atualizam, compreendem e desenvolvem tais potencialidades "é um mútuo aprendizado: entre técnicos, entidades e comunidade mudanças de paradigmas (HS)”.

Embora cada um tenha um modo peculiar de compreender as situações todos vivem num mesmo mundo havendo aspectos comuns em suas existências que os permitem conviver e partilhar das mesmas experiências. Existe, em outras palavras, uma realidade paupável, da qual todos fazem parte embora possam dar-lhe um colorido pessoal, com a maneira peculiar de ser a "integralidade passa pela pessoa do 
profissional, sua prática depende de seu olhar;" isto é de sua "visão de mundo a partir da profissão - identificação $(M C)$ ”. Agindo de acordo com o modo no qual compreende as situações e, devido a esse modo aparecer como necessidade de averiguar se as percepções estão de acordo, as ações serão tão eficientes e eficazes quanto forem adequadas à compreensão da realidade dos acontecimentos.

$\mathrm{Na}$ escuta profunda dos debates e estudos travados na mesa do Conselho foi possível observar a vivência de angústia, não no sentido intimista com o qual o sujeito se sente mal, sem conseguir saber o por quê. Porquanto a aflição vivida pelo grupo apresentava-se tão intensa que forçava a reflexão sobre a mesma, tentando encontrar os motivos que levaram a esse sofrimento e os meios possíveis e a disposição para tentar superá-lo ou, pelo menos, aliviá-lo. Principalmente na referência a “mudança na visão ou cosmovisão do profissional e identificação pessoal $(M C)$ ” dos agentes sociais que atuam na rede.

Nas diversas reuniões, debates, deliberações e encaminhamentos a angústia constituiu-se como fator de mobilização para a construção de alternativas. Entretanto, paradoxalmente, por maior que fosse o empenho em encontrá-las e obter certa segurança e a tranqüilidade, estas chegavam a ser alcançadas por alguns momentos de sintonia e conhecimento. Levando a hipóteses e chegando a algumas conclusões a respeito dos planejamentos daquilo que se pretendera para o futuro, desta forma as entidades sociais se estabelecem "como uma extensão da política de governo parceiras, trabalhando em conjunto sem sobrepor (a entidade como parte da rede de proteção);" de forma institucional sugere-se "que a entidade tenha foco no seu local de origem e desenvolva a cultura de trabalhar integrada à rede pública e com outras 
entidades;" como um modo de interagir com o usuário e comunidade observando " $a$ necessidade de ter o perfil e de ouvir a opinião da criança/adolescente para evitar o risco de falar na criança sem falar dela - dar voz ao usuário (M)”.

A integralidade como uma idéia referência esteve sempre presente e foi de enorme importância. Pois, além de proporcionar uma base, de certo modo, objetiva, para explicar e planejar as ações, foi responsável pelo avanço alcançado, nas várias áreas de atuação, avanço que pôde se constituir como meio para viver a adequação entre práticas que constituem o ponto de partida e o fundo sobre o qual as reflexões se realizavam e, também, a possibilidade de elaborações continuamente revistas e ampliadas. Neste sentido a integralidade, se configura como paradigma, para compreender o desafio cultural de romper com formas cristalizadas de se entender e realizar ações técnicas e que conformam padrões de intervenção no campo da atenção à saúde seja na área médica ou na promoção social. A integralidade se estabelece, então, como proposição a padrões reducionistas tornados tradição na prática em saúde.

A integralidade estabelecida como paradigma propõe possibilidades de elaborações que são continuamente revistas e ampliadas "replanejar ou providenciar uma ação com relação àquela entidade; com ações de uma política integrada; a gente ta buscando suprir tudo isso - investimentos em recursos humanos (HS)". Essa possibilidade sinaliza para a presença concreta da pessoa do profissional a um lugar que lhe permite, no cotidiano, vivenciar um fluxo existencial crivado de paradoxos e riscos que dificultam ter segurança para agir. A insegurança permanece mesmo quando se procura apoiar em experiências passadas, agindo em termos do que já se conhece, pois o presente é abertura para o futuro e este sempre contém imprevistos, é imponderável. 
Nesta pesquisa, na intersecção entre a saúde pública e a promoção social, a pessoa que se encontra no agente social foi desvelando o objeto de estudo. Mas, também desvelando-se a si mesmo na ocorrência dos fatos que acarretam a diminuição ou abundância de recursos pessoais, e também, na restrição de condições externas da vida, que podem transformar-se em estímulos para que ele se dedique à descoberta e atualização de possibilidades das quais, até então, não havia percebido possuir ou não as havia valorizado suficientemente, para se dispor a atualizá-las. O importante é que no reconhecimento da integralidade, em suas diversas manifestações, se reconheceu as limitações para que se possa buscar "investimento, qualificação dos profissionais, melhorar e normatizar atendimento $(M C)$ ".

\section{Reflexões sobre este estudo}

Durante o ano que acompanhamos as atividades do Comdicas, seja na observação participante ou nas entrevistas semi estruturadas, o discurso prevalente sinalizou e, mesmo, centrou-se em alguns momentos, na pessoa do agente social, na dependência da cosmovisão do profissional de saúde, daquele responsável pelas ações técnicas na rede de serviços para o bom desenvolvimento da integralidada. Na síntese das entrevistas esse ocorrido chamou-nos a atenção. Ao longo dos discursos as falas sobre a necessidade de formação, de mundança na sua cosmovisão, de maior envolvimento no quefazer, enfim, sobre a fragilidade do ator social em lidar com a integralidade. 
Encontramos na obra de Gilles Lipovetsky, principalmente em seu livro "Os tempos hipemodernos", uma possibilidade de reflexão sobre essa questão. Este filósofo francês, nascido em Millau, no ano de 1944. É protagonista de acirradas polêmicas em todo o mundo. Teórico do individualismo, aprofunda o conceito de hipermodernidade criado por ele. O homem hipermoderno de Lipovetsky está fragilizado pelo medo em uma era de exageros. E esse homem hipermoderno nos possibilitou refletir sobre as concepções de integralidade do agente social que, desenvolvendo sua ação em saúde na intersecção entre o campo da saúde pública e da promoção social, vivencia a fadiga sobre a integralidade. E, do modo em que, as circunstâncias que o envolvem na sociedade atual, proporciona-lhe determinado contexto que o desafia a incorporar em sua prática uma diversidade polissêmica sobre o paradigma de integralidade.

Estamos bastante acostumados a ouvir manifestações preocupadas com a situação da saúde na sociedade contemporânea. Esta preocupação certamente está relacionada, primeiro, com uma maior transparência, advinda dos meios de comunicação, que deixa aflorar comportamentos insalubres e descobertas no campo da saúde que antes permaneciam desapercebidas; e, segundo, com a gravidade das consequências que esses comportamentos e descobertas podem acarretar, devido tanto ao fator potencializador dos atuais recursos científico-tecnológicos - como a agressão ao meio ambiente ou a manipulação genética -, quanto à sua capacidade de manejar domínios fundamentais da existência humana - como a interrupção ou prolongamento da vida ou a pesquisa com células-tronco embrionárias. Estas possibilidades geram uma preocupação de dimensões talvez nunca antes registradas nos mais diferentes domínios do conhecimento e das atividades humanas. A busca quase febril por novos modelos de comportamentos saudáveis, que possibilitem melhor qualidade de vida e seu 
prolongamento, esbarra na valorização hedonista do momento, da primazia dos interesses individuais. $\mathrm{O}$ balanço destes processos mostra desesperança e desânimo com relação ao futuro de nossa sociedade porque a situação sinaliza, pelo menos por hora, para o narcisismo individualista e hedonista ao que nos parece constituir um quadro de prejuízo à saúde considerada como fenômeno social (Lipovetsky, 2004; Goergen, 2005).

A profunda ruptura na história da humanidade, introduzida a partir da modernidade, traduziu-se num discurso que exalta as conquistas da ciência e confia na possibilidade de um progresso ilimitado que desenha para o homem um futuro melhor neste mundo. A razão criaria - esta era a aposta moderna - as condições para uma vida melhor, mais feliz e justa (Lipovetsky, 2004; Perestrelo, 2006; Alves, 1987).

As catástrofes que marcaram o século vinte desautorizaram a Razão e ofuscaram o brilho de suas promessas. Se a modernidade desacreditou o passado por meio da afirmação de uma racionalidade técnico científica, os descaminhos desta deslegitimaram-na como única garantia de um futuro melhor. Eliminados o passado como nostalgia e o futuro como esperança, o refúgio que sobrou foi o presente. E a ele o homem se entregou por inteiro. Precisamente o presente que, reduzido a tempo de passagem, a tradição menosprezava, e que a modernidade queria superar em troca de um futuro melhor. Este trânsito é teoricamente fixado pelo chamado movimento pósmoderno que ocorreu a partir da segunda metade do século $X^{1}{ }^{1}$. Segundo suas teses, a

\footnotetext{
${ }^{1}$ Ao longo da década de 70 foi introduzido o conceito 'pós-moderno' para qualificar o estado cultural das sociedades, tidas como desenvolvidas. Este conceito que surgiu primeiramente no campo da arquitetura e muito rapidamente se difundiu por outros campos da atividade humana passou a designar "ora o abalo dos alicerces absolutos da racionalidade e os fracassos das grandes ideologias da história, ora a poderosa dinâmica da individualização e da pluralização de nossas sociedades”. (Lipovetsky, 2004)
} 
racionalidade moderna, incapaz de cumprir suas promessas, seria substituída por uma nova lógica da sedução, da hedonização da vida, da consagração do individualismo, da espetacularização de tudo, do elogio ao presente em repulsa ao passado que já não é e ao futuro que não chega. A pós-modernidade apresentou-se como aquele momento histórico em que todos os esquemas institucionais que impunham limites à emancipação individual se desfaziam e desapareciam, abrindo espaço para os desejos individuais e subjetivos. Ela se autodefinia como um tempo em que as grandes ideologias embasadas em estruturas socializantes e a crença na verdade absoluta cairiam em descrédito, perdendo sua autoridade e atração. O discurso pós-moderno postula o fím da racionalidade moderna e o início de uma nova era (Lipovetsky, 1983: 98-110).

Vazio de sentido positivo, a designação 'pós-moderno', após muito debate e polêmica, se encontra hoje em decadência. Alguns autores, como é o caso de Lipovetsky, antes defensor ferrenho dos pressupostos pós-modernos, se dispuseram a reconhecer que os anúncios da nova era foram apressados e se revelaram inconsistentes. Parece que a tese de uma temporalidade dominada em todos os âmbitos do humano pelo precário e pelo efêmero, bem como a primazia absoluta do aqui e agora resulta de uma leitura linear e pouco dialética da história. Hoje é relativamente fácil colher evidências das contradições que desestabilizam a suposta derrocada radical de todas as ideologias da modernidade (Goergen, 2005).

Depois das transformações científico-tecnológicas que envolveram conceitos fundamentais como o espaço e o tempo, tal posicionamento se tornou insustentável. Ocorreram, sim, mudanças profundas, incontestavelmente visíveis a todos. Mas daí concluir que tais mudanças trouxeram consigo uma guinada radical da história e a 
negação de todos os fundamentos anteriores é outro engano. O pós-modernismo decreta o passado como morto e extinto e anuncia a chegada do reino da autonomia e liberdade como se esse pudesse ser alcançado pela simples superação dos enquadramentos religiosos, sociais, políticos e ideológicos tradicionais. Além desse exagero, que se torna cada vez mais notório, os pós-modernos não se deram conta de que a fuga para diante trouxe consigo novos enquadramentos, tão fortes ou mesmo piores que os anteriores. Piores porque dão aos homens a ilusão de liberdade e autonomia, quando, na verdade, aumentam, embora sutilmente, a sua dependência.

Não se trata aqui de defender um retorno ao passado, à modernidade e seus modelos, conforme foram concebidos em seu início, mas de argumentar que não é legítimo perder de vista a evolução dialética e contraditória da história. É verdade que num primeiro momento, privatiza-se o Estado, a religião e a família e impõe-se o mercado, a tecnociência e o individualismo. Mas num segundo movimento manifestamse as contradições. O social, os valores, os sentidos, as transcendências começam a reocupar, no horizonte do humano, sobre novos fundamentos e sob novas formas e dinâmicas os seus lugares. Neste cenário, do ponto de vista pedagógico, o que mais carece é a reflexão dialética, a resistência às imposições e a inauguração de uma nova positividade, capaz de fornecer ao ser humano novos sentidos, novas utopias, novos limites. Há uma série de acontecimentos ${ }^{2}$ indicativos de que se inicia uma resistência contra o mercado e o consumismo, contra o relativismo axiológico e o individualismo hedonista, contra a violência e a banalização da vida, contra a atomização social e a despolitização, contra a fabricação de falsas necessidades e promessas de felicidade pelo

\footnotetext{
${ }^{2}$ Refiro-me aos recentes movimentos sociais como a defesa do meio ambiente, das organizações pela paz, da luta pelos direitos das minorias, mas, particularmente, ao incremento que vem tendo a elaboração de uma nova ética, ainda que mínima, que transcenda os limites estreitos do hedonismo presentista.
} 
consumo. Se estiver correta esta leitura, diria que se inicia a nova via de sobrevivência e de felicidade e, portanto, de vida saudável.

Talvez, esta nova consciência devolva ao ser humano a dimensão perdida do social e do político, essencial à condição humana. Parece que todos os movimentos e iniciativas que hoje buscam alternativas ao imediatismo consumista valorizam precisamente esta dimensão social. Estas características indicam que o eixo do presente volta a ser o social, como condição incontornável da condição humana. Tal pressuposto apresenta-se claro quando voltamos nosso olhar para o estabelecimento do SUS, no contexto do movimento sanitário brasileiro, como uma proposta não apenas de atenção à saúde mas, antes, de visão do ser humano e sociedade. O SUS ao apresentar paradigmas para a política em saúde pública, como a humanização, descentralização, universalização entre outros, e, mesmo, sem esquecer a integralidade, propõe um determinado modelo de sociedade. Sinaliza, com seus paradigmas, ideais democráticos do movimento sanitário brasileiro que respondiam ao contexto no qual se estabeleceu.

O ser humano perdendo a crença num futuro necessariamente melhor e sabendo que teria de lutar por ele, dominando e orientando os mecanismos como a ciência e os recursos tecnológicos sabe que a felicidade futura dependia de um projeto de solidariedade política. Se vivemos um período de ofuscamento da idéia de progresso e se, por alguns momentos, o pós-moderno nos induziu a esquecer o sentido trágico da existência e a necessidade da luta para superá-lo, estamos nos convencendo de que a idéia de progresso ainda não é uma página virada da história. O debilitamento da crença num progresso mecânico e necessário, de um lado, e a frustração da idéia de presente absoluto, de outro, conscientizam a sociedade da necessidade de seu engajamento na 
construção do futuro. Nem o encantamento com as ciências e suas descobertas e nem a visão catastrófica de um futuro trágico colocam-se como alternativas. O futuro depende do homem e da visão social de suas circunstâncias esse é o questionamento que o SUS apresenta à sociedade (Kujawski,1994; Gasset, 1987).

O sonho do indivíduo autônomo e liberto do que considerava as ideologias socializantes transformou-se em pesadelo pleno de ameaças que espreitam por todos os lados. Na verdade, o que parecia autonomia e liberdade transformou-se em ameaça iminente. É certo que as aspirações lúdico-hedonistas continuam povoando as aspirações da maioria, mas percebe-se também, em contornos cada vez mais nítidos, os temores e inquietações que dali irradiam. O otimismo que cercava o individualismo, o presentismo, o hedonismo e o aqui e agora está se esgotando. A medicina já não se dedica apenas à saúde do indivíduo porque percebe que o indivíduo não pode ser sadio se o ambiente estiver doente. Percebe-se que a saúde individual depende da saúde coletiva. Não basta tratar os doentes; é preciso cuidar da saúde pública, dos alimentos, do meio ambiente para que a saúde de cada um possa estar garantida. Tal reorientação pode ser percebida não apenas ao nível dos projetos mais amplos, mas na própria postura individual das pessoas (Pelicioni, 1999). A necessidade não só de prever, mas de preservar o futuro mostra que a proposta pós-moderna não é suficiente para a felicidade e a vida boa/saudável. Como diz Lipovetsky, citado por Sebastien Charles,

\footnotetext{
"hoje, a obsessão consigo mesmo se manifesta menos no ardor do gozo que no medo da doença e do envelhecimento, na medicalização da vida. Narciso está menos enamorado de si mesmo que aterrorizado pelo quotidiano, pelo próprio corpo e por um ambiente social que ele considera agressivo". (Lipovetsky, 2004: 28)
}

O que ainda caracteriza o momento presente é o processo de subjetivação e individualização que transfere as tragédias sociais para o âmbito do indivíduo. O trágico 
sobrevive no indivíduo e sua solução transfere-se do campo social, da coletividade para a subjetividade e a individualidade. $\mathrm{O}$ indivíduo é considerado culpado pela sua desgraça e também o único responsável pela sua redenção. Assim, rompem-se os elos do social e esvai-se a força dos ideais transcendentes e comunitários, restringindo-se tudo à solidão e debilidade da subjetividade individual. Apartado do coletivo e culpabilizado pela sua situação, o indivíduo torna-se fraco e manipulável a partir de pequenas recompensas que satisfazem por sua passividade e submissão. É impressionante como ao ler as narrativas dos conselheiros, sob esse ponto de vista, aparece a responsabilização do agente social e do profissional de saúde pelo fracasso ou sucesso de uma política pública inspirada em princípios de integralidade. Os ideais de bem-estar e de felicidade foram deslocados do contexto social e transferidos para o âmbito privado e individual. Desta forma, a consciência se apazigua nos limites do privado e não mais se perturba em razão de problemas sociais pelos quais já não se sente responsável (Lipovetsky, 1989, 2004).

No entanto, como disse, não se deve exagerar esquecendo o movimento dialético que co-habita nestas tendências da cultura contemporânea. Paralelamente aos grandes movimentos de individualização e esmaecimento dos ideais coletivos registra-se, também, a tendência oposta: os comportamentos de orientação social continuam presentes e, arriscaria dizer, até crescem em muitos setores das atividades humanas. $\mathrm{O}$ exemplo mais visível talvez seja o da ecologia e o da saúde ${ }^{3}$ onde emerge claramente uma nova ética do cuidado. Se, de um lado, o capitalismo neo-liberal conseguiu enfraquecer o Estado e provocar seu afastamento das atividades sociais, de outro,

\footnotetext{
${ }^{3}$ Complementam o assunto as reflexões de Philippi e Pelicioni, FSP/USP, Jornal da USP, 7 a 13/6/1999, pag. 2.
} 
crescem o engajamento das Ongs - Organizações não Governamentais -, e das associações que reivindicam a responsabilização social dos setores produtivos.

Um simples olhar à nossa volta é suficiente para constatar um mundo pleno de contrastes e contradições. Este mundo ambíguo coloca-se, ao mesmo tempo, como risco e necessidade principalmente ao jovem adolescente. Ele precisa tanto construir sua identidade psíquica, sua personalidade individual por conta de sua condição de ser sujeito, quanto assumir uma identidade social, uma inserção sócio-cultural por conta de sua natureza social. Esta é a condição, complexa e dilemática, da realização do ser humano. Não fora isso o bastante, o caminho dessa realização está ladeado de convites e seduções que, carregados de interesses, querem conduzir o jovem ora para um, ora para outro lado. Ao sistema econômico, por exemlpo, interessa dispor de um indivíduo competente, hábil no manejo de conhecimentos e técnicas, maleável e adaptável aos intentos do capital. A cidadania, de outra parte, exige um ser autônomo, independente e crítico, capaz de decidir, por conta própria os destinos de sua vida no interior de um projeto de co-responsabilidade social. O mundo econômico exige competência, competitividade, a busca de vantagens; a cidadania requer conhecimento e reconhecimento da diferença, solidariedade e busca do bem-estar social.

No campo da saúde este cenário de conflitos e contradições se revela particularmente desafiador. Pressupor um conjunto harmônico e consensual de ações em saúde não é possível. Como não é possível pressupor um conjunto harmônico e consensual de valores, embora os conflitos muitas vezes sejam silenciados mediante métodos autoritários usados pelas forças hegemônicas. Basta lembrar alguns valores possíveis como a humildade, o respeito e a obediência ou, na contraparte, a auto- 
afirmação, a capacidade crítica e a autonomia. Cada um destes conjuntos de valores representa um caráter distinto na atuação do profissional de saúde. Torna-se intrigante a questão de como, no interior de uma mesma sociedade, é possível tanta ambigüidade. A resposta, na verdade, é simples se admitirmos que a sociedade se compõe de camadas ou classes heterogêneas, cujos projetos e expectativas sociais são, também, distintos e conflitantes.

Isto nos permite concluir, desde logo, que é ideológica a imagem homogeneizante que muitos teóricos desenham a respeito dos valores e ideais das práticas em saúde. Bem como a tendência homogeneizante das ciências da saúde em compreender o fenômeno do adolescente e humano em geral.

Diante dessa realidade ambivalente, poderíamos imaginar que as ciências da saúde tivessem condições, senão de determinar, pelo menos de indicar os objetivos que deveriam ser buscados ou evitados para a promoção de uma vida e de uma sociedade saudáveis. No entanto, muitas vezes, se limitam, de um lado, a constatar as doenças predominantes e tidas como importantes pela área médica e, de outro, a promover e subsidiar ações em torno dos objetivos e valores que, em determinadas circunstâncias econômicas, seriam os mais indicados para a intervenção aos indivíduos e à sociedade como um todo (Duarte, 1994; Perestrelo, 2006).

A polissêmica noção de integralidade que emergiu das entrevistas questiona, no estado atual de nossos conhecimentos e práticas, o modelo diagnóstico e toda a estrutura médica baseada em uma patogenia biológica. O estabelecimento da mudança no campo da saúde que considerasse o paradigma de integralidade levaria a mudança no 
diagnóstico de doentes que seria a de não mais considerar, por exemplo, a úlcera, mas o ulceroso, ou, numa linguagem politicamente correta, o portador de úlcera; não mais a hipertensão mas o hipertenso; não mais a doença mental mas o portador de sofrimento mental, e assim por diante. Assim, o olhar a partir da integralidade questiona desde a educação médica até a arquitetura dos hospitais, passando pela técnica diagnóstica e terapêutica de todos os profissionais da área médica e do campo da saúde. Será que o paradigma de integralidade é, nesse sentido, mais uma idéia bem intencionada do campo da saúde pública?

Não nos parece. Lipovetsky com seu homem hipermoderno concede um suporte a nossa análise de que se a integralidade for levada às últimas consequiências o ensino de todos os profissionais de saúde será radicalmente transformado. Terão como diretriz o homem em permanente interação social e envolto por um mundo complexo de fenômenos naturais, associados e/ou submetidos a contingências culturais. E tudo isso compreendido como um todo em transformação, em um vir-a-ser permanente, e, mesmo assim, arrastando uma identidade, um "eu" ao qual essa unidade se aferra fortemente para não submergir ao caos. Mesmo essa unidade humana é sub-unidade dentro de uma unidade maior. Quando se relaciona forma um grupo, uma família, quando se expande forma uma sociedade, uma nação até o conceito vago mas, tragicamente real, de humanidade.

É possível um simples profissional hipermoderno, da saúde ou da promoção social, manter esse paradigma presente em seu cotidiano, na sua prática, no seu ato terapêutico? Para ter essa perspectiva consciente é preciso alhear-se da sociedade na qual está inserido. Engajar-se na experiência humana, própria ou de outrem, percebendo 
que no seu quefazer é obrigado à parcialização, a um recorte da realidade, o qual infelizmente, é tomado como um todo. E cada recorte forma um novo "todo". Assim, os agentes de saúde, os agentes sociais, cada especialista, convive com um todo que, em realidade, é o recorte de determinada realidade. A integralidade é, nesse sentido, uma utopia, uma idéia referência, proposta pelo SUS. Um modo de olhar, de focalizar, as ações e práticas em saúde sem perder de vista o todo ou reduzi-las apenas às ações médicas.

O mesmo ocorre em qualquer outra área do conhecimento. A focalização não reduz um campo vasto a uma fração epistêmica. Essa fração, na experiência, forma um todo, mesmo que no discurso se afirme a existência de uma totalidade maior que a pequena fração daquela dada convivência circunstancial. Naquela clássica experiência de Gestalt com figuras combinadas ou vemos a velha ou a jovem. Nunca as duas. Embora saibamos que elas existam. É a percepção racional de uma realidade maior, abrangente, que comporta uma estruturação mais legítima, mais integral (Goergen, 2005; Lipovetsky, 1984; Perestrello, 2006). .

Á necessidade de superar os dogmatismos tradicionais, não resta outra alternativa senão o entendimento dialógico-discursivo entre todos os agentes interessados e responsáveis pelo processo de saúde para formular objetivos e valores a serem buscados na prática. Constitui parte dessa atividade crítica da teoria, desvendar o caráter ideológico de certas formulações e, afirmar os valores democráticos. Mesmo assim, tais entendimentos conduziriam apenas a consensos precários, sempre sujeitos a novas tematizações discursivas e correspondentes reformulações. 
Vivemos num contexto de mudança numa velocidade que nos alcançou de sobressalto e que, por isso, nos deixa inseguros e desorientados. Vivemos também a exponencial ambigüidade da objetivação/subjetivação, que exige um alto grau de autonomia das pessoas para que consigam encontrar sentidos e caminhos para sua vida nesse emaranhado de apelos e contradições que a todos envolve, do início ao fim da vida, quanto mais em sua vida profissional(Goergen, 2005; Lipovetsky, 1984).

Não há garantias para que a conduta humana conduza a uma vida saudável. Precisamos aceitar a idéia de que o homem e a sociedade são sempre imperfeitos, cheios de ambigüidades e de contradições. A proposição que a todos se coloca é a de construir, no contexto de tempos tão turbulentos e inseguros, práticas integrais em saúde que se fundamentem em princípios e que contribuam para ações eficazes desvinculadas do meramente circunstancial e de conveniências momentâneas. 


\section{REFERÊNCIA BIBLIOGRÁFICA}

ADORNO, R. C. F.; CASTRO A. L. "O exercício da sensibilidade: pesquisa qualitativa e a saúde como qualidade"; São Paulo: 3(2):172-185, 1994

ADORNO / HORKHEIMER, "Dialética do esclarecimento"; (Trad. Guido A. de Almeida), Rio de Janeiro: Jorge Zahar Editor, 1985

ALVES, R. "Filosofia da ciência”; 10ªd.; São Paulo: Brasiliense, 1987

AMATUZZI, M. M. “Pesquisa do vivido"; In:___ "Por uma psicologia humana”; Campinas: Ed. Alínea, 2001: (4) 53-60

BARROS, J. A. C. "Pensando o processo saúde-doença: a que responde o modelo biomédico?’; São Paulo: Saúde e Sociedade 11(1):53-66, 2002

BOEMER, M. R. 'Empatia: proposta de abordagem fenomenológica'; Rev. Enf. USP São Paulo: 18(1): 23-29; 1984

"A condução de estudos segundo a metodologia fenomenológica";

Rev. Latino-americana Enf. São Paulo: 2(1): 83-94; 1994

BRASIL. “Constituição: República Federativa do Brasil”; Centro Gráfico do Senado Federal, Brasília, 1988

BRASIL. Ministério da Saúde. Secretaria de Assistência à Saúde - SAS. Departamento de Assistência e Promoção à Saúde - DAPS. Coordenação Materno-Infantil - COMIN. Serviço de Assistência à Saúde do Adolescente. Normas de Atenção à Saúde Integral de Adolescente - Vol. I - Diretrizes Gerais para Atendimento de Adolescentes. Acompanhamento do Crescimento e Desenvolvimento. Distúrbios da Puberdade. Desenvolvimento Psicológico do Adolescente. Brasília: Ministério da Saúde, 1993

BRASIL. Ministério da Saúde. Secretaria de Assistência à Saúde - SAS. Departamento de Assistência e Promoção à Saúde - DAPS. Coordenação Materno-Infantil - COMIN. Serviço de Assistência à Saúde do Adolescente. Normas de Atenção à Saúde Integral de Adolescente - Vol. II - Saúde Mental. Sexualidade na Adolescência. Brasília: Ministério da Saúde, 1993

CAPALBO, C. "A fenomenologia e a experiência do outro"; in: POKLADEK, D. D. "A fenomenologia do cuidar: prática dos horizontes vividos na área da saúde, educacional e organizacional”; São Paulo: Vitor, 2004

“Alternativas metodológicas de pesquisa”; In: Sem. Nac. Pesq. Em Enf. 3; Florianópolis; 1984. Anais... Florianópolis: Ed. UFSC ; 1984: 130-157.

CARVALHO, A. S. “Metodologia da entrevista: uma abordagem fenomenológica"; São Paulo: Ed. Agir; 1987 
CONTINI, M. L. J., KOLLER, S. H. org. "A adolescência e Psicologia: práticas e reflexões críticas”; Rio de Janeiro: Conselho Federal de Psicologia, 2002

COSTA, A. M. "Integralidade na atenção e no cuidado a saúde”; São Paulo: Saúde e Sociedade v. 13, n.03, p. 5-15, set/dez, 2004

CORETH, E. “Questões fundamentais da hermenêutica”; Trad. C. L. de Mattos; São Paulo: EPU/Edusp; 1973

CRITELLI, D. M. “Analítica do sentido: uma aproximação e interpretação do real de orientação fenomenológica”; São Paulo: Educ/Brasiliense; 1996

DARTIQUES, A. “O que é fenomenologia”; Trad. Maria José J. G. de Almeida; Rio de Janeiro: Eldorado Tijuca, 1973

DUARTE, J. E. S. “Avanços e desafios do SUS: o papel do município e da academia”; São Paulo: Saúde e Sociedade 11(1):37-52, 2002

FERLA, A.A.; CECCIM, R.B.; PELEGRINI, M.L.M. "Atendimento Integral: a escuta da gestão estadual do SUS"; In: PINHEIRO, R.; MATTOS, R.A. "Construção da integralidade"; Rio de Janeiro: UERJ, IMS, ABRASCO, 2003

GASSET, O. “A rebelião das massas”; Trad. De Marilene P. Michael; São Paulo: Martins Fontes; 1987

GOERGEN, P., "Pós-modernidade, ética e educaçã̃"; Campinas: Autores Associados, 2005

HEIDEGGER, M. “O ser e o tempo"; Petrópolis: Vozes 2ª ed. ; 1988 “Kant e o problema da metafísica”, São Paulo: Abril, 1983

KUJAWSKI, G. de M. "Ortega y Gasset a aventura da razão"; São Paulo: Moderna,1994

LIPOVETSKY, G. "A era do vazio - ensaio sobre o individualismo contemporâneo"; Lisboa: Anthropos, 1989

LIPOVETSKI, G.; CHARLES, S., “Os tempos hipermoderno”; trad. Mario Vilela, S.Paulo: Editora Barcarolla, 2004

MATTOS, R.A.de "Os sentidos da integralidade: algumas reflexões acerca de valores que merecem ser defendido"; In: PINHEIRO, R.; MATTOS, R.A.de "Os sentidos da integralidade na atenção e no cuidade à saúde”; Rio de Janeiro: UERJ, IMS, AB

MARTINS, J.; BICUDO, M. A. V. “A pesquisa qualitativa em psicologia: fundamentos e recursos básicos”; São Paulo: Moraes, 1989 
MINAYO, M. C. de S. "O desafio do conhecimento: pesquisa qualitativa em saúde”; São Paulo - Rio de Janeiro: HUCITEC-ABRASCO, 1992

PELICIONE, M. C. F. “As interrelações entre a educação, saúde e meio ambiente”; Biológico São Paulo, vol. 61. n.2 pag. 75-78, jul/dez. 1999

PERESTRELLO, D. “A medicina da pessoa”; 5a ed.; São Paulo: Editora Atheneu, 2006

PINHEIRO, R.; MATTOS, R.A.de "Os sentidos da integralidade na atenção e no cuidade à saúde”; Rio de Janeiro: UERJ, IMS, ABRASCO, 2001

PINHEIRO, R.; MATTOS, R.A. “Construção da integralidade: cotidiano, saberes e práticas em saúd”; Rio de Janeiro: UERJ, IMS, ABRASCO, 2003

PHILIPPI, A. Jr, PELICIONI, M. C. F. “Saúde e Agenda 21”; Jornal da USP, São Paulo, 7 a 13/6/1999, pág. 02

QUIVY, R.;CAMPENHOUDT, L. V. "Manual de investigação em ciências sociais"; Lisboa: Gradiva; 2003

SPINK, M. J.; MENEGON, V. M. "A pesquisa como prática discursiva: superando os horrores metodológicos"; In: SPINK, M.J., organizadora. "Práticas discursivas e produção de sentidos no cotidiano: aproximações teóricas e metodológicas"; São Paulo: Cortez Editora; 1999.

VALLE, E. R. M. “Câncer infantil: compreender e agir”; Campinas: Editorial Psy; 1987 


\section{BIBLIOGRAFIA CONSULTADA}

ABERASTURY, A. e KNOBEL, M. "Adolescência Normal”; (Trad. de Suzana M. Garagoray Ballve) Porto Alegre: Artes Médicas, 1981

ALVES, D. S. "Integralidade nas políticas de saúde mental”; In: PINHEIRO, R.; MATTOS, R. A. Sentidos da integralidade na atenção e no cuidado à saúde. Rio de Janeiro: UERJ/IMS/ABRASCO, 2001, p. 167-176

ALVARENGA, A.T. de "A Saúde Pública como campo de investigação interdisciplinar e a questão metodológica”; São Paulo: Saúde e Sociedade. 3(2):22-41, 1994.

BASTIDE, R. “Sociologia das doenças mentais”; São Paulo: Cia Edit. Nac., 1967

BRASIL. Ministério da Saúde. "Programa Saúde do Adolescente. Bases programáticas"; $2^{\mathrm{a}}$ ed., Brasília; 1996

CANNON, R. C. et al. "Saúde e desenvolvimento da juventude brasileira: construindo uma agenda nacional”; Brasília: Ministério da saúde, Secretaria de políticas de saúde; 1999.

CASSIRER, Esnest, “Antropologia Filosófica”; São Paulo: Mestre Jou, 1972 (175-218)

CAVALCANTI, R. da C. "Adolescência”; In: VITIELLO, N. [et. al] Adolescência hoje. São Paulo: Roca, 1988

CONNOR, S. “Cultura pós-moderna - introdução às teorias do contemporâneo”; São Paulo: Loyola, 1992

COTRIM, B. C. "Potencialidade da técnica qualitativa grupo focal em investigação sobre abuso de substâncias"; São Paulo: Ver. Saúde Pública, 30(3): 285-93, 1996

CHAVES JUNIOR, E. de O. "Políticas de Juventude: evolução histórica e definição"; In: Cadernos Juventude, Saúde e Desenvolvimento. Brasília: Ministério da Saúde, Secretaria de Políticas de Saúde, 1999

COUTINHO, M. F. G.; BARROS R.R. "Adolescência: uma abordagem prática”; São Paulo: Ed. Atheneu (pag. 209-230); 2001

DALMOLIN, B. M. "Trajetória da saúde mental no Brasil: da exclusão a um novo modelo"; O Mundo da Saúde - São Paulo, ano 24 v. 24 ( n.1 jan./fev. 2000)

DIMITROV, P. “Chegamos a 2000 d.C., e a saúde para onde vai?”; O Mundo da Saúde - São Paulo, ano 24 v. 24 (5-9) n.1 jan./fev. 2000

DURKEIN, E. “As regras do método sociológico”; São Paulo: Cia Ed. Nac., 11ª 1984

ECO, U. “Como se faz uma tese”; São Paulo: Perspectiva, 2004 
FERLA, A.A.; CECCIM, R.B.; PELEGRINI, M.L.M. "Atendimento Integral: a escuta da gestão estadual do SUS" In: PINHEIRO, R.; MATTOS, R.A. "Construção da integralidad";. Rio de Janeiro: UERJ, IMS, ABRASCO, 2003

FORGHIERI, Y. C. "Psicologia fenomenológica - fundamentos, método e pesquisas"; São Paulo: Pioneira, 1993

KANT, E. "Sobre a pedagogia”; (Trad. Francisco Cock Fontanella) Piracicaba: Editora Unimep, 1996

LEFÈVRE, F., org. "O discurso do sujeito coletivo: uma nova abordagem metodológica em pesquisa qualitativa”; Caxias do Sul: Educs, 2000

LELOUP, J.Y. "Uma consciência anunciada"; in, GROUPE 21, O homem do futuro - um ser em construção, São Paulo: Triom, 2002

LEONTIEV, A. “O desenvolvimento do psiquismo”; Lisboa: Livros Horizonte, 1978

LINTON, R. "Campo de divisões da antropologia”; In: MUSSOLINI, G. Evolução, raça e cultura. São Paulo: Cia Editora Nacional, 1978

LYON, D. “Pós Modernidade”; São Paulo: Paulus,1994

MATTELART, A. "História da sociedade da informação"; São Paulo: Edições Loyola, 2002

PELICIONE, M. C. F. "As interrelações entre a educação, saúde e meio ambiente”; Biológico São Paulo, vol. 61. n.2 pag. 75-78, jul/dez. 1999

ROMANO, R. "Ciência para justiça e equiidad”; Saúde e Sociedade, São Paulo, v. 13, n. 1 , p. 53-66, jan/jul 2002

ROSA, M. "Psicologia evolutiva: psicologia da vida adulta”; Petrópolis: Vozes, 1984

VITIELLO, N. [et. al] "Adolescência hoje"; Comissão Nacional de Estudos sobre a Adolescência, São Paulo: Roca, 1988 


\section{TERMO DE CONSENTIMENTO LIVRE E ESCLARECIDO}

O tema de pesquisa refere-se ao desafio/dificuldade de uma compreensão sobre A Integralidade numa Rede de Proteção Social do Adolescente. Temos como pressuposto básico que as experiências existentes na cidade de Suzano permitam contribuir para a reflexão e o re-pensar a atenção psicossocial do adolescente.

Os objetivos desta pesquisa têm por prioridade: Compreender a noção de integralidade emergente em uma Rede de Proteção Social à Criança e ao Adolescente, caracterizada como uma atenção psicossocial.Caracterizar o lugar da integralidade no interior dessa rede de serviços e sua contribuição em uma abordagem de atenção psicossocial ao adolescente. Refletir sobre as possibilidades e limites dessa noção de integralidade sob a perspectiva de algumas circunstâncias que a inserem na sociedade contemporânea .

As atividades que compõem a metodologia desta pesquisa envolvem: a) observação participante - participação do pesquisador nas reuniões do Conselho; e, b) entrevistas semi-estruturadas - entrevistas individuais com alguns conselheiros.

Durante o processo de pesquisa os participantes terão a liberdade de recusar-se a participar ou retirar seu consentimento em qualquer momento e serão garantidos o sigilo e a privacidade dos sujeitos quanto aos dados confidenciais. A publicidade de seus resultados estarão sob a orientação do Comitê de Ética da FSP/USP e do protocolo de ética do CNS/96.

Agradecemos a oportunidade que certamente promoverá uma experiência ímpar de reflexão e produção de conhecimento para a atuação junto aos adolescentes e crianças do município de Suzano.

Orientador: Prof. Dr. Cornélio Pedroso Rosenburg - Fone: 3066-7703

Aluno: Sandro da Rocha Vieira - Fone: 4751-1233/7157-9655

Sujeito de pesquisa:

Suzano, dia/ mês/ano 